\title{
Revisiting cAMP signaling in the carotid body
}

\author{
Ana R. Nunes ${ }^{1 *}$, Andrew P. Holmes ${ }^{2}$, Sílvia V. Conde ${ }^{1}$, Estelle B. Gauda ${ }^{3}$ and Emília C. Monteiro ${ }^{1}$ \\ ${ }^{\prime}$ CEDOC, Chronic Diseases Research Center, NOVA Medical School/Faculdade de Ciências Médicas, Universidade Nova de Lisboa, Lisboa, Portugal \\ ${ }^{2}$ School of Clinical and Experimental Medicine, University of Birmingham, Birmingham, UK \\ ${ }^{3}$ Neonatology Research Laboratories, Department of Pediatrics, Johns Hopkins Medical Institutions, Johns Hopkins University, Baltimore, MD, USA
}

\section{Edited by:}

Rodrigo Iturriaga, Pontificia

Universidad Católica de Chile, Chile

Reviewed by:

Ana Obeso, University of Valldolid,

Spain

Julio Alcayaga, Universidad de Chile, Chile

${ }^{*}$ Correspondence:

Ana R. Nunes, Chronic Diseases Research Center, NOVA Medical School/Faculdade de Ciências Médicas, Universidade Nova de Lisboa, Campo Mártires da Pátria, 130, 1169-056 Lisboa, Portugal e-mail: rita.nunes@fcm.unl.pt
Chronic carotid body (CB) activation is now recognized as being essential in the development of hypertension and promoting insulin resistance; thus, it is imperative to characterize the chemotransduction mechanisms of this organ in order to modulate its activity and improve patient outcomes. For several years, and although controversial, cyclic adenosine monophosphate (cAMP) was considered an important player in initiating the activation of the CB. However, its relevance was partially displaced in the 90s by the emerging role of the mitochondria and molecules such as AMP-activated protein kinase and $\mathrm{O}_{2}$-sensitive $\mathrm{K}^{+}$channels. Neurotransmitters/neuromodulators binding to metabotropic receptors are essential to chemotransmission in the $C B$, and CAMP is central to this process. CAMP also contributes to raise intracellular $\mathrm{Ca}^{2+}$ levels, and is intimately related to the cellular energetic status (AMP/ATP ratio). Furthermore, CAMP signaling is a target of multiple current pharmacological agents used in clinical practice. This review (1) provides an outline on the classical view of the CAMP-signaling pathway in the $\mathrm{CB}$ that originally supported its role in the $\mathrm{O}_{2} / \mathrm{CO}_{2}$ sensing mechanism, (2) presents recent evidence on CB CAMP neuromodulation and (3) discusses how CB activity is affected by current clinical therapies that modify cAMP-signaling, namely dopaminergic drugs, caffeine (modulation of $A_{2 A} / A_{2 B}$ receptors) and roflumilast (PDE4 inhibitors). CAMP is key to any process that involves metabotropic receptors and the intracellular pathways involved in $\mathrm{CB}$ disease states are likely to involve this classical second messenger. Research examining the potential modification of CAMP levels and/or interactions with molecules associated with $\mathrm{CB}$ hyperactivity is currently in its beginning and this review will open doors for future explorations.

Keywords: cAMP signaling, carotid body, pharmacology, phosphodiesterase inhibitors, adenylyl cyclase, adenosine, dopamine, antipsychotics

\section{INTRODUCTION}

Adequate homeostatic regulation of arterial oxygen $\left(\mathrm{P}_{\mathrm{a}} \mathrm{O}_{2}\right)$, carbon dioxide $\left(\mathrm{P}_{\mathrm{a}} \mathrm{CO}_{2}\right), \mathrm{pH}$ and blood glucose are important processes in physiology. Highly specialized chemosensory type I cells of the mammalian carotid bodies ( $\mathrm{CBs}$ ) sense acute changes in $\mathrm{P}_{\mathrm{a}} \mathrm{O}_{2}, \mathrm{P}_{\mathrm{a}} \mathrm{CO}_{2}$ and $\mathrm{pH}$, and, upon stimulation, release neurotransmitters (NTs) that either inhibit or activate chemosensory fibers projecting into the central nervous system (CNS). The functional consequence of CB stimulation is the initiation of important cardiovascular, respiratory and metabolic reflexes. These reflexes include an increase in minute ventilation, a sympathetically mediated elevation in heart rate and peripheral vasoconstriction and an augmentation in adrenaline release from the adrenal medulla, with the latter leading to an increase in arterial blood glucose concentration.

Recently, interest in $\mathrm{CB}$ physiology has attracted considerable attention because of its emerging associations with chronic cardiovascular disease (McBryde et al., 2013). CB dysfunction and increases in chemoafferent discharge promote neurogenic hypertension in sleep disordered breathing (Prabhakar and Peng, 2004), chronic heart failure (Schultz et al., 2013) and essential hypertension (Abdala et al., 2012; McBryde et al., 2013). Moreover, the $\mathrm{CB}$ is a principal regulator in initiating insulin resistance in animal models of prediabetes and metabolic syndrome (Ribeiro et al., 2013). Therefore, the modulation of $\mathrm{CB}$ function may be necessary to prevent and treat some of these conditions. A good understanding on the modulation of the cellular processes occurring downstream of the $\mathrm{CB}$ transduction machinery, may not only promote drug development that modify $\mathrm{CB}$ chemodischarge to prevent or treat disease, but will also increase the awareness that $\mathrm{CB}$ chemodischarge can be an inadvertent side effect of drugs used to treat other diseases.

CB type I cells contain molecular sensors that, when activated, trigger transduction cascades that produce cellular depolarization, $\mathrm{Ca}^{2+}$ influx and NT and/or neuropeptide secretion. The list of characterized NTs/neuromodulators (NMs) and respective receptors in the $\mathrm{CB}$ has increased considerably over the last 20 years (Table 1). These NTs/NMs have the potential to activate metabotropic and ionotropic receptors located on type I cells (autoreceptors), on afferents of the carotid sinus nerve (CSN, post-synaptic receptors), or both, exerting either excitatory or inhibitory actions (Table $\mathbf{1}$ ). The activation of 
Table 1 | Receptors in the carotid body.

\begin{tabular}{|c|c|c|c|c|c|c|c|}
\hline NT/NM & \multicolumn{3}{|c|}{ Receptor } & $\begin{array}{l}\text { CSN } \\
\text { activity }\end{array}$ & Species & Localization & References \\
\hline \multirow{2}{*}{ 范 } & $\mathrm{D}_{1}$ & $\mathrm{G}_{\mathrm{s}}$ & - & $(-) ?$ & Rat, cat, rabbit & $\begin{array}{l}\text { PG, SCG, whole } \mathrm{CB} \text {, } \\
\text { blood vessels }\end{array}$ & $\begin{array}{l}\text { Almaraz et al., 1991; Bairam et al., } \\
1998\end{array}$ \\
\hline & $\mathrm{D}_{2}$ & $\mathrm{G}_{\mathrm{i}} / \mathrm{G}_{\mathrm{o}}$ & - & $(-)^{a}$ & $\begin{array}{l}\text { Rat, rabbit, cat, } \\
\text { mice, human }\end{array}$ & $\begin{array}{l}\text { Whole } \mathrm{CB}, \mathrm{PG} \text {, and } \mathrm{SCG} \text {, } \\
\text { type I cells of } \mathrm{CB} \text {, nerve } \\
\text { endings }\end{array}$ & $\begin{array}{l}\text { Dinger et al., 1981a; Mir et al., } \\
\text { 1984; Czyzyk-Krzeska et al., 1992; } \\
\text { Bairam and Khandjian, 1997; } \\
\text { Fagerlund et al., 2010; Kåhlin et al., } \\
2010\end{array}$ \\
\hline \multirow[t]{2}{*}{ 岀 } & $\alpha_{2 A}$ & $\mathrm{G}_{\mathrm{i}} / \mathrm{G}_{0}$ & - & $(-)$ & Rat, rabbit, cat & $\begin{array}{l}\text { SCG, whole CB, type I } \\
\text { cells, sympathetic } \\
\text { innervation, blood } \\
\text { vessels? }\end{array}$ & $\begin{array}{l}\text { Kou et al., 1991; Almaraz et al., } \\
\text { 1997; Gauda, } 2002\end{array}$ \\
\hline & $\beta_{2}$ & $\mathrm{G}_{\mathrm{s}}$ & - & $(+)$ & Rat & Whole CB & Mir et al., 1983 \\
\hline \multirow{4}{*}{$\frac{0}{\frac{1}{0}}$} & $\mathrm{M}_{2} / \mathrm{M}_{4}$ & Gi/Go & - & $?$ & Cat, rabbit & Type I cells, CB, SCG, PG & $\begin{array}{l}\text { Dinger et al., 1981b, 1991; } \\
\text { Shirahata et al., 2004; Bairam et al., } \\
2006\end{array}$ \\
\hline & $M_{1} / M_{3}$ & $\mathrm{G}_{\mathrm{q}} / \mathrm{G}_{11}$ & - & $(+)$ & Cat, rabbit & Type I cells, CB, SCG, PG & $\begin{array}{l}\text { Dinger et al., 1981b, 1991; } \\
\text { Shirahata et al., 2004; Bairam et al., } \\
2006\end{array}$ \\
\hline & $\begin{array}{l}\alpha 4, \alpha 7, \text { and } \beta 2 \text {, } \\
\alpha 4 \beta 2 \text { hete }\end{array}$ & - & $\sqrt{ }$ & $(+)$ & Rat & $\begin{array}{l}\text { Type I cells, PG, CSN } \\
\text { afferents }\end{array}$ & $\begin{array}{l}\text { Obeso et al., 1997; Zhong and } \\
\text { Nurse, 1997; Gauda, 2002; He } \\
\text { et al., 2005; Conde and Monteiro, } \\
\text { 2006a; Niane et al., 2009; Meza } \\
\text { et al., } 2012\end{array}$ \\
\hline & $\alpha 3, \alpha 7, \beta 2$ & & & & Human & Whole CB & Fagerlund et al., 2010 \\
\hline \multirow{3}{*}{ 是 } & $\begin{array}{l}\mathrm{P} 2 \mathrm{X}_{2 / 3}, \mathrm{P} 2 \mathrm{X} 3 \\
\mathrm{P} 2 \mathrm{X}\end{array}$ & - & $\sqrt{ }$ & $(+)$ & $\begin{array}{l}\text { Rat, cat, } \\
\text { humans, mice }\end{array}$ & $\begin{array}{l}\text { PG afferents, whole CB, } \\
\text { SCG }\end{array}$ & $\begin{array}{l}\text { Prasad et al., 2001; Rong et al., } \\
\text { 2003; Alcayaga et al., 2007; Bairam } \\
\text { et al., 2007; Fagerlund et al., } 2010\end{array}$ \\
\hline & $\mathrm{P} 2 \mathrm{Y}_{1}$ & $\begin{array}{l}\mathrm{G}_{\mathrm{q}} / \mathrm{G}_{11} \\
\mathrm{G}_{\mathrm{i}} / \mathrm{G}_{0}\end{array}$ & - & $(-) ?$ & Rat & Type I cells & Xu et al., 2005 \\
\hline & $\mathrm{P} 2 \mathrm{Y}_{2}$ & $\begin{array}{l}\mathrm{G}_{\mathrm{q}} / \mathrm{G}_{11} \\
\mathrm{G}_{\mathrm{i}} / \mathrm{G}_{0}\end{array}$ & - & $(-) ?$ & Rat & Type II cells & Xu et al., 2003 \\
\hline \multirow{3}{*}{$\frac{\circ}{8}$} & $A_{1}$ & $\mathrm{G}_{\mathrm{i}} / \mathrm{G}_{0}$ & - & $(-) ?$ & $\begin{array}{l}\text { Rat } \\
\text { Rabbit }\end{array}$ & $\begin{array}{l}\text { PG } \\
\text { Type I cells }\end{array}$ & $\begin{array}{l}\text { Gauda, } 2002 \\
\text { Rocher et al., } 1999\end{array}$ \\
\hline & $A_{2 A}$ & Gs & - & $(+)$ & Rat, human & $\begin{array}{l}\text { Whole CB, post } \\
\text { synaptically on CSN }\end{array}$ & $\begin{array}{l}\text { Kobayashi et al., 2000; Fagerlund } \\
\text { et al., } 2010\end{array}$ \\
\hline & $A_{2 B}$ & Gs & - & $(+)$ & Rat & $\begin{array}{l}\text { Whole CB, type I cells, } \\
\text { PG }\end{array}$ & $\begin{array}{l}\text { Kobayashi et al., 2000; Conde et al., } \\
\text { 2006b, } 2008\end{array}$ \\
\hline
\end{tabular}


Table 1 | Continued

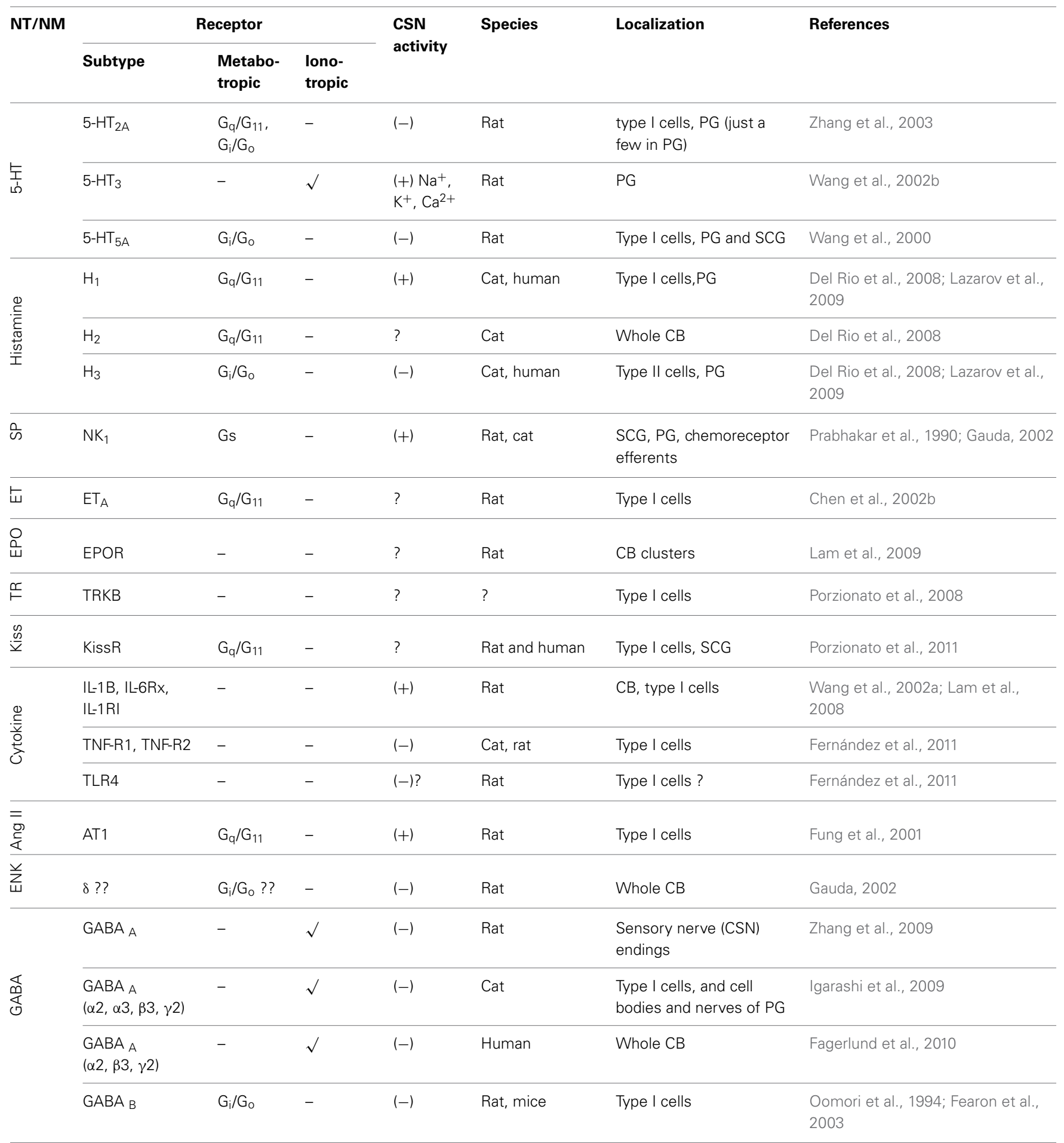

${ }^{a}$ Mainly inhibitory, but excitatory in rabbit (Iturriaga et al., 2009). ${ }^{b}$ Although less characterized in rat, the $n A c h R \alpha 3,4,5,7$, and $\beta 2,4$ are present in type I cell, $\alpha 7$ in the CNS afferents and $\alpha 3,4,7$, and 32,4 in PG; the mAchR $M 1$ and $M 2$ are in type I cells, M1 in CSN afferents and M1 and M2 in PG neurons of cat and rabbit (for a revision, Shirahata et al., 2007). ?, suggested, but no direct evidences/not known; NT/NM, neurotransmitters/neuromodulators; DA, dopamine; NE/E, norepiniphrine/epiniphrine; NE, norepiniphrine; Ach, acetylcholine; ATP, adenosine triphosphate; Ado, adenosine; 5-HT, serotonine; GABA, gamma-aminobutyric acid; ENK, enkephalins; SP, substancia P; ET, endothelins; TR, trophin; Angll, Angiotensin; AC, adenylyl cyclase; +, excitatory; -, inhibitory; CB, carotid body; SCG, superior cervical ganglion; $P G$, petrosal ganglion. 
excitatory postsynaptic receptors is translated into an increase of CSN action potential frequency, and it is this signal that is conveyed to the CNS. Stimulation of excitatory autoreceptors induces an increase in $\left[\mathrm{Ca}^{2+}\right]_{i}$ and subsequent further release of NTs/NMs.

Retrograde communication between petrosal ganglion (PG) neurons and $\mathrm{CB}$ type I and type II cells is another source of NTs/NMs release in the CB. PG neurons present catecholaminergic traits (Katz et al., 1983; Katz and Black, 1986) and catecholamines (CAs) are released from cultured PG neurons upon stimulation (Iturriaga et al., 2003). Moreover, nitridergic autonomic neurons located in the glossopharyngeal and carotid nerve may also modulate the CB function (Campanucci et al., 2012). The pannexin-1 channel opening have been recently shown to be important in reciprocal cross-talk pathways between type I and type II cells, particularly in purinergic transmission (ATP and Ado) (Nurse, 2014).

The specific NT profile, receptor expression and cellular effects changes with early postnatal development, and in some cases exhibits interspecies variability [e.g., dopamine (DA) exerts inhibitory effects on the $\mathrm{CB}$ in most species, except rabbit, (Iturriaga et al., 2009)].

Despite the numerous different NTs/NMs released from the type I cell, even under basal conditions, a convergence upon a common signaling pathway could confer the overall CB excitability and establish its sensitivity to physiological stimuli. Cyclic adenosine monophosphate (cAMP) is a common downstream signaling molecule of numerous receptors expressed in the type I cells, and is coupled to cellular energetic status (AMP/ATP ratio). This article therefore aims to summarize how changes in $\mathrm{CB}$ cAMP levels in physiology, pathology and following pharmacological intervention may be central to alterations in type I cell excitability leading to chemoafferent discharge and cardiorespiratory and metabolic reflex responses.

\section{CLASSICAL UNDERSTANDING OF cAMP-SIGNALING PATHWAY IN THE CAROTID BODY}

An involvement of cAMP in the CB chemotransduction (late 70 s-early 80 s) was originally prompted by the identification of secreted NTs and their receptor-mediated effects on CB chemoreceptor responses (Table 1). These secreted NTs included DA (Gonzalez and Fidone, 1977), acetylcholine (ACh) (Eyzaguirre et al., 1965), noradrenaline (NA), substance P, serotonin and prostaglandin $\mathrm{E}_{2}$ (Pérez-García et al., 1993 for early references), and adenosine (Ado) (McQueen and Ribeiro, 1981; Monteiro and Ribeiro, 1987; Conde and Monteiro, 2004), acting through specific G-protein coupled receptors (Table 1). For those NTs that confer an excitatory response, cAMP levels were increased, while for those that confer an inhibitory response cAMP levels were decreased.

Fitzgerald and co-workers, were the first to identify cAMP in the CB cat homogenates (Fitzgerald et al., 1977). Subsequent studies showed that injection of isoprenaline increased cAMP accumulation in the rat CB (Mir et al., 1983) and elevated chemoafferent discharge frequency in cat and rabbit models via stimulation of beta-adrenoreceptors (Folgering et al., 1982). Moreover, administration of dibutyryl cyclic AMP (db-cAMP,
cAMP analog) was found to mimic the excitatory effect of adenosine on chemosensory discharge (McQueen, 1983).

Following these findings, a new wealth of evidence emerged supporting a role for the CAMP in CB chemotransduction and/or chemotransmission (Wang et al., 1989, 1991a; Fidone et al., 1990; Pérez-García et al., 1990; Cachero et al., 1996; Summers et al., 2002). Multiple investigations reported rises in CB cAMP accumulation following hypoxia exposure (Fidone et al., 1990; Pérez-García et al., 1990), an effect that appeared to be specific for chemoreceptor tissue (Wang et al., 1989) and was dependent on NT release (Pérez-García et al., 1990). Activation of adenylyl cyclases (AC), by forskolin (FSK), potentiated CB CA secretion and CSN discharge frequency over a range of $\mathrm{O}_{2}$ tensions from 30 to $0 \%$, in the intact rabbit $\mathrm{CB}$ preparation (Almaraz et al., 1991; Wang et al., 1991a). In addition, FSK and db-cAMP both inhibited the type $\mathrm{I}$ cell $\mathrm{O}_{2}$-sensitive $\mathrm{K}^{+}$current, emphasizing similarities between excitatory cAMP and hypoxic signaling cascades (López-López et al., 1993). Hypercapnia exposure also elevated cAMP content (Pérez-García et al., 1990) and FSK augmented the hypercapnic CA release (Pérez-García et al., 1991). In isolated rabbit CB type I cells, cAMP analogs potentiated inward $\mathrm{Ca}^{2+}$ current in a manner that was comparable with hypercapnia (Summers et al., 2002). Despite these data, it was not universally accepted that endogenous cAMP was physiologically relevant in the CB.

Delpiano et al. reported, using an in vitro preparation of the cat $\mathrm{CB}$, that anoxia exposure induced only small increases in cAMP levels (Delpiano and Acker, 1991). Furthermore, severe whole body hypoxia exposure caused both increases and decreases in CB cAMP accumulation (Delpiano and Acker, 1991), and short periods of hypoxia $(2.5-5 \mathrm{~min})$ failed to alter the cAMP levels in rat CB (Mir et al., 1983). $\mathrm{K}^{+}$and $\mathrm{Ca}^{2+}$ currents, both important in hypoxic chemotransduction, were shown to be insensitive to an array of cAMP analogs in the rat $\mathrm{CB}$ type I cells (Hatton and Peers, 1996); inwardly rectifying $\mathrm{Cl}^{-}$ current is directly activated by cAMP (Carpenter and Peers, 1997). The inter-experiment variability, differences in species and age, in $\mathrm{CB}$ dissection methods, $\mathrm{O}_{2}$ and $\mathrm{CO}_{2}$ stimulus intensity, duration of incubation periods, $\mathrm{CB}$ preparations (in vitro, in vivo, whole $\mathrm{CB}$ vs. isolated cells or carotid sinus nerve (CSN) preparations) and cAMP detection methods (radioimmunoassay, enzyme-immunoassay, protein binding saturation assays) have all been credited for the discrepancies reported in the literature regarding the relevance of cAMP signaling in CB function (Table 2).

Thus, there was still a requirement to further characterize and better understand the physiological significance of cAMP in the CB. To consider cAMP signaling as a physiological modulator of the chemoreceptor activity, disruption of cAMP generation, metabolism, or its intracellular effectors would need to be synonymous with functional modification of basal CB activity and/or its responses to hypoxia/hypercapnia. $[\mathrm{cAMP}]_{\mathrm{i}}$ is tightly regulated by $\mathrm{AC}$, by enzymes involved in its degradation (phosphodiesterases; PDE), and by the fluctuating activity of downstream effectors (Kamenetsky et al., 2006). The AC activities are highly integrated and determined by receptor-mediated changes in Gstimulatory $\left(G_{s}\right)$ and $G$-inhibitory $\left(G_{i}\right)$ proteins as well as by 


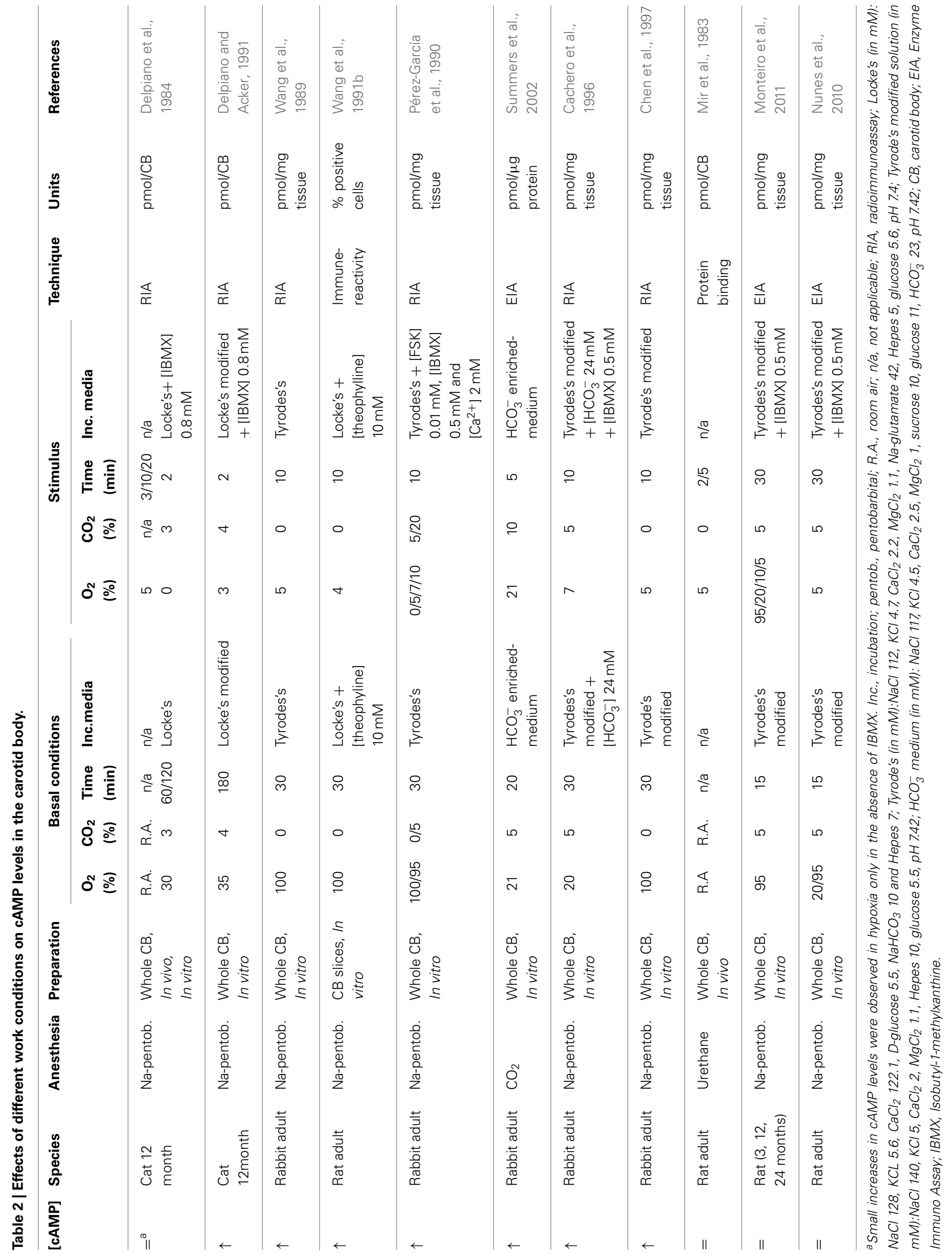


$\mathrm{CO}_{2}$ and $\mathrm{HCO}_{3}^{-}$(depending on specific $\mathrm{AC}$ isoforms- see below). $[\mathrm{cAMP}]_{\mathrm{i}}$ can also be modified by direct diffusion from one cell to another through gap junctions (Bevans and Harris, 1999) or through transport to the extracellular milieu where it produces regulatory functions in multiple tissues (for a review Bankir et al., 2002; Hofer and Lefkimmiatis, 2007). Downstream effectors classically include protein kinase A (PKA) (Taylor et al., 1990), cyclic nucleic gated ion channels (Craven and Zagotta, 2006) and exchange proteins activated by cAMP (EPACs) (De Rooij et al., 1998).

Recently, better research tools have become available to more accurately detect intracellular cAMP and its regulation, thereby allowing us re-examine the enzymatic regulation of cAMP within the $\mathrm{CB}$ and its intracellular targets, during normoxia, hypoxia and hypercapnia conditions.

\section{NOVEL FINDINGS CHARACTERIZING THE ENZYMATIC REGULATION OF CAMP ACCUMULATION IN THE CAROTID BODY}

Over the last decade, the enzymes involved in the cAMPpathway signaling in the $\mathrm{CB}$ have been identified, and their activity modulated by natural stimuli. Novel findings have been recently reported as to how $\mathrm{O}_{2} / \mathrm{CO}_{2}$ exposure affects the $\mathrm{CB}$ cAMP-signaling.

\section{THE ROLE OF ADENYLYL CYCLASES IN THE CAROTID BODY ACTIVITY}

The AC are enzymes that catalyze the synthesis of cAMP through the cyclization of ATP. There are two main classes: the classic NT-sensitive transmembrane (tmAC) and the more recently described soluble adenylyl cyclase (sAC) (for a review see Kamenetsky et al., 2006). The activity of the former is primarily influenced by extracellular signals (e.g., NTs, hormones, pharmacological agents) and is further subclassified in terms of G-protein associations, $\mathrm{Ca}^{2+}$ related signaling pathways (Halls and Cooper, 2011) and more recently by $\mathrm{CO}_{2}$ interactions (Townsend et al., 2009; Cook et al., 2012). sAC is regulated directly by $\mathrm{HCO}_{3}^{-}$and $\mathrm{Ca}^{2+}$, in a $\mathrm{pH}$ independent manner, as being shown primarily in testis and further extended to other organs as described below (Chen et al., 2000; Jaiswal and Conti, 2003).

The presence of the different AC mRNA transcripts was only reported recently; intact rat CBs (16-17 postnatal days) express tmAC1, tmAC2, tmAC3, tmAC4, tmAC6 and tmAC9, with tmAC1, tmAC4 and tmAC6 exhibiting the highest fold expression level (Nunes et al., 2013). sAC mRNA has also been identified, and is expressed at greater levels in the $\mathrm{CB}$ than in non-chemosensitive neuronal tissues (Nunes et al., 2009). The studies on AC mRNA were performed in whole $\mathrm{CB}$ (containing type I and type II cells, vessels, nerve endings, etc.). Whether there is a specific and clearly distinguished physiological function for each AC isoform, in the CB is unknown. Many agents that target cAMP signaling pathways are also likely to non-selectively act on the respective G-protein coupled receptors or PDE, thus making individual AC targeting challenging. However, in other tissues, individual $\mathrm{AC}$ isoforms do demonstrate unique functionality and this has led to increased interest in identifying specific AC isoforms as potential drug targets (Pierre et al., 2009). Genetic association studies have been valuable in unraveling the importance of specific AC in physiology and disease. For instance, a polymorphism of AC6 have been associated with alterations in blood pressure and heart rate regulation in humans (Hodges et al., 2010). Point mutations of the AC3 gene are also associated with decreased insulin release in animal models of type 2 diabetes (Abdel-Halim et al., 1998). Correlating specific mutations in tmAC genes with $\mathrm{CB}$ dysfunction and hypertension across patient populations may help refine $\mathrm{CB}$ disease related research. This data is currently unavailable but could be invaluable given the emerging relevance of the $\mathrm{CB}$ in cardiovascular system pathology.

Although ATP binding to ionotropic receptors likely mediates excitatory chemodischarge to hypoxia, DA and Ado are two key participants in modifying type I cell and/or post-synaptic cAMP via their modification of tmAC activity. Hypoxia-induced raises in type I cell $\left[\mathrm{Ca}^{2+}\right]$ and ${ }^{3} \mathrm{H}$-DA neurosecretion are depressed in the presence of specific $\mathrm{D}_{2}$ receptor agonists (Benot and LópezBarneo, 1990; Carroll et al., 2005; Conde et al., 2008), an effect that is associated with a reduction in CB cAMP content in both conditions. Deficiency of $\mathrm{D}_{2}$ receptors in adult mice blunts type I cell neurosecretion, but not CSN responses to hypoxia, possibly consistent with opposing pre-synaptic and post-synaptic neuromodulation (Prieto-Lloret et al., 2007). Systemic inhibition of Ado receptors decreases, but does not abolish, the CB mediated acute phase of the hypoxic ventilatory response (Lee et al., 2005). Using in vitro CB preparations, Conde et al. reported that blocking Ado receptors depresses hypoxic induced CA release and chemoafferent activity, an effect that is greater in milder rather than severe hypoxic conditions (Conde et al., 2006b, 2012a). $D_{2}$ receptors are negatively coupled to $\mathrm{AC}$ while Ado $\mathrm{A}_{2 \mathrm{~B}}$ are positively coupled to AC. Blockage of Ado $A_{2 B}$ receptors counteract the decrease in cAMP elicited by $D_{2}$ receptor activation suggesting an $A_{2 B}$ and $D_{2}$ autoreceptor interaction accounting for overall $[\text { cAMP }]_{i}$ in the type I cell (Conde et al., 2008). In acutely dissociated type I cells, Ado $\mathrm{A}_{2 \mathrm{~A}}$ receptor inhibition abolishes the $\left[\mathrm{Ca}^{2+}\right]_{\mathrm{i}}$ elevations evoked by Ado (Xu et al., 2006). Since both $A_{2 A}$ and $A_{2 B}$ receptors exert their actions through excitation of tmACs (reviewed in Ribeiro and Sebastião, 2010), it is the increase in $[\mathrm{cAMP}]_{\mathrm{i}}$, that is most likely to account for its overall chemostimulatory function. Accordingly, directly inhibiting tmACs with SQ22536, does indeed depress hypoxic induced CA-secretion (Rocher et al., 2009).

These findings do not, however, confine CB cAMP content to the regulation of DA and Ado. Essentially any NT/receptor system that is coupled to tmAC will alter cAMP levels in the $\mathrm{CB}$, including histamine/ $\mathrm{H}_{1}$ and $\mathrm{H}_{3}$ receptors (Del Rio et al., 2008, 2009; Thompson et al., 2010), adrenaline/ $\beta$-adrenergic receptors (Mir et al., 1983; Hauton et al., 2013), pituitary adenylate cyclaseactivating protein (PACAP)/PAC 1 receptor (Xu et al., 2007; Roy et al., 2013), among others (also see Table 1).

sAC activity has been described in numerous tissues where changes in $\mathrm{HCO}_{3}^{-} / \mathrm{CO}_{2}$ are essential to their function. For instance in the testis, where sAC is highly expressed, $\mathrm{SAC}$ mediates sperm maturation and acquisition of motility (Buck et al., 1999; Hess et al., 2005). In the kidneys it regulates recycling of V-ATPse (Pastor-Soler et al., 2003), in airway epithelial cells sAC regulates the ciliary beat frequency (Schmid et al., 2007), and in corneal 
endothelium it plays a role in the activation of the cystic fibrosis transmembrane conductance regulator (Sun et al., 2004). sAC mRNA has now been identified in the whole CB, and although the sAC mRNA cellular localization has not been demonstrated, it is expressed at greater level in the intact organ than in other non-chemosensitive neuronal tissues (Nunes et al., 2009, 2013).

The physiological role of sAC in $\mathrm{CO}_{2}$ sensing was only recently studied in the $\mathrm{CB}$ chemoreceptors and its function appears somewhat equivocal. Contrary to those that reported rises in cAMP content, and PKA dependent $\mathrm{Ca}^{2+}$ current during isohydric hypercapnia (Pérez-García et al., 1990; Summers et al., 2002), observations from our laboratory indicate that increasing the $\mathrm{HCO}_{3}^{-} / \mathrm{CO}_{2}$ ratio from $24 \mathrm{mM} / 5 \%$ (normocapnia) to $44 \mathrm{mM} / 10 \%$ (isohydric hypercapnia) does not alter cAMP content, PKA activity or CSN discharge frequency and, under these conditions, these assays were insensitive to the sAC inhibitor KH7 (Nunes et al., 2013). We did however show that KH7 decreased cAMP content under basal conditions and we speculated that sAC contributes more to normocapnic rather than hypercapnic $[\mathrm{CAMP}]_{\mathrm{i}}$, at least in the rat $\mathrm{CB}$. Examining the extent of sAC $\mathrm{HCO}_{3}^{-}$saturation in normocapnia/normoxia and whether this alters type I cell $\left[\mathrm{Ca}^{2+}\right]_{i}$, chemoafferent frequency or responses to hypoxia/acidosis may thus be an important area for future investigation.

\section{THE ROLE OF PHOSPHODIESTERASES IN THE CAROTID BODY ACTIVITY}

PDE catalyze the hydrolysis of the 3-cAMP phosphate bonds of adenosine 3,5-cyclic monophosphate to AMP. According to the pharmacological principle that the regulation of the second messenger degradation can often make a more rapid and larger percentage change in concentration than comparable regulation of the rates of synthesis, PDEs are important modulators of CAMP levels, preventing uncontrolled diffusion of cAMP through the cell and consequently contributing to the formation of localized pools or gradients of cAMP within the cell (Lugnier, 2006). There are 11 known distinct PDE isoforms, each displaying unique substrate affinity and variable adjustment to endogenous co factors and pharmacological inhibitors (Bender and Beavo, 2006).

Uncharacterized PDE was first identified in the CB in 1977 by Hanbauer and Lovenberg, and these studies provided the first evidence for an $\mathrm{O}_{2}$ dependent cAMP affinity (Hanbauer and Lovenberg, 1977). From then on, studies aiming to indirectly assay $\mathrm{CB}$ AC activity and manipulate cAMP levels in responses to different oxygen concentrations have been performed in the presence of the xanthine 3-isobutyl-1-methylxantine (IBMX), a non-selective PDE inhibitor $\left(k_{i}=1-10 \mathrm{mM}\right.$, Dousa, 1999 and $I C_{50}=2-50 \mathrm{mM}$, Bender and Beavo, 2006) with potential to block Ado receptors $\left(k_{i}=7.28 \mathrm{mM}\right.$, Daly et al., 1991). A particular limitation of IBMX is its inability to inhibit PDE7 and PDE8 (Lugnier, 2006).

The PDE4 isoform was recently proposed as a major regulator of cAMP-hydrolyzing activity in the rat $\mathrm{CB}$ (Nunes et al., 2010). PDE4 comprises four subtypes (PDE4A, PDE4B, PDE4C, and PDE4D) with at least 35 known splice variants (Bender and Beavo, 2006). Selective pharmacological inhibition of PDE4 increases CB cAMP content in normoxia and causes even greater rises during hypoxia. These increases are however considerably lower than those observed in the presence of IBMX, suggesting a physiological role of additional isoforms (Nunes et al., 2010). However, at the time of this review, no functional data relating PDE4 activity with CB responses to hypoxia or hypercapnia has been published; functional studies are necessary to further strengthen the position of PDE4 in the CB. Intriguingly, given that PDE4 activity increases with chronic hypoxia in $\mathrm{O}_{2}$-sensitive pulmonary arteries and blood (Maclean et al., 1997; Spoto et al., 1998; Millen et al., 2006), a compensatory role for PDE4 to counter CB hyperactivity, although speculative, is plausible. That said, the consequences of chronic hypoxia or chronic intermittent hypoxia exposure on PDE activity in the $\mathrm{CB}$ remains to be explored.

\section{THE ROLE OF CAMP EFFECTORS IN THE CAROTID BODY ACTIVITY: PROTEIN KINASE A, EXCHANGE PROTEIN ACTIVATED BY cAMP AND CYCLIC NUCLEOTIDE GATED CHANNELS}

PKA is the classical downstream effector of cAMP. It is a holotetrameric serine/theonine kinase composed of two regulatory and two catalytic subunits. Four CAMP molecules bind to the regulatory subunits, each with two cAMP binding sites. The cAMP binding promotes the dissociation of the catalytic subunits that bind ATP to become catalytically active and phosphorylate serine and threonine residues in intracellular targets such as A-kinase anchoring proteins (AKAPS) and ion channels. AKAPs tether PKA to particular cellular organelles and to the plasma membrane confining the PKA signaling to a small pool within the cells (Beene and Scott, 2007). In the nucleus, PKA can phosphorylate transcription factors, such as cAMP response element binding protein (CREB), and thus regulate gene expression.

A physiological role for PKA in $\mathrm{CB}$ chemotransmission is at present controversial. In dissociated rabbit type I cells, PKA inhibition by PKA inhibitor (PKAi) diminishes the rise in $\mathrm{L}$-type $\mathrm{Ca}^{2+}$ current in response to isohydric hypercapnia (Summers et al., 2002). However, we reported that PKA activation status, as measured by Fluorescent Resonance Energy Transfer (FRET) based reporters, is unaltered during isohydric hypercapnia in isolated rat type I cells (Nunes et al., 2013). Multiple blockers of PKA have no effect on hypoxic CA-secretion in the intact rat CB preparation (Rocher et al., 2009). In contrast, acute rises in type I cell $\left[\mathrm{Ca}^{2+}\right]_{\mathrm{i}}$ evoked by Ado and PACAP are essentially abolished by PKA inhibition with H89 (10 $\mu \mathrm{M})$ (Xu et al., 2006, 2007). Sustained plateau CSN activity mediated by PACAP is inhibited by only $41 \%$ in the presence of $\mathrm{H} 89$, in a preparation including the carotid bifurcation- CB-CSN-superior cervical ganglion (Roy et al., 2013). Furthermore, type I cell activation by methylcholine is sensitive to tmAC inhibition but not $\mathrm{H} 89$ inhibition, which suggests that cAMP signaling cascades in the $\mathrm{CB}$ are independent of PKA activation (Thompson and Wyatt, 2011). Whether these multiple discrepancies reflect fundamental species differences, different preparations (whole $\mathrm{CB}$ vs. cultures or type I cells) or other unidentified experimental factors are unclear, but precaution must be taken when using $\mathrm{H} 89$ due its reported nonspecific inhibitory effect (Lochner and Moolman, 2006). In cellular preparations, it is likely that transmitters released from type I cells are lost to the superfusate and so their potential excitatory 
or inhibitory autoregulation of the type I cell chemosensitivity to hypoxia or hypercapnia is not apparent. Additionally, the contribution of retrograde communication (PG neurons to CB cells) should be also taken in account (Katz et al., 1983; Katz and Black, 1986; Iturriaga et al., 2003) as well as the new concept of tripartite sensory synapse between type I, type II and PG neurons (Nurse, 2014). Also, we now know that the contribution of the NTs to the hypoxic chemosensitivity in the $\mathrm{CB}$ depends on hypoxic intensity meaning that different hypoxic intensities will evoke the release of different NTs (Conde et al., 2012a) and therefore the differences observed in PKA activation can reflect distinct hypoxic intensities/mediators involved.

Different effects of PDE4 inhibitors on cAMP accumulation induced by hypoxia (Nunes et al., 2010), could suggest a different degree of PDE phosphorylation induced by differences in PKA activity mediated by hypoxia (Bender and Beavo, 2006).

Complex cAMP driven mechanisms through PKA and extracellular signal regulated kinase (ERK) mediated phosphorylation can modify PDE4 specific isoforms activity and subsequently alter the sensitivity to selective inhibitors (Bender and Beavo, 2006). Thus, determining whether acute hypoxia causes PDE4 activation by PKA or ERK mediated phosphorylation would be of interest.

EPAC is a guanine nucleotide exchange factor (GEF) for the RasGTPase homologs, Rap1 and Rap2. EPAC is composed of two regions: an $\mathrm{N}$-terminal regulatory region containing a cAMPbinding site and a C-terminal catalytic region, with GEF activity (De Rooij et al., 1998). In the inactive conformation, EPAC is folded and the regulatory domain functions as an auto-inhibitory domain. cAMP binding unfolds the protein, allowing Rap to bind (for a review Gloerich and Bos, 2010). Rap GTPases cycle between an inactive GDP-bound and an active GTP-bound state, with GEFs mediating the exchange of GDP for GTP. GTPase-activating proteins then convert Rap to the inactive form. The activated Rap-GTP activates a variety of different mechanisms in the cell: promotes integrin-mediated cell adhesion, gap junction formation and $\mathrm{ERK}_{1 / 2}$ MAPK-mediated protein phosphorylation, stimulates phospholipase C- $\varepsilon$ which hydrolyzes PIP2 to generate diacylglycerol, and the $\mathrm{Ca}^{2+}$ mobilizing second messenger $\mathrm{IP}_{3}$ (for a review Holz et al., 2006).

Rocher and co-workers initially proposed a physiological role for EPAC in the $\mathrm{CB}$ by examining the effects of the EPAC activator (8-pCPT-2'-O-Me-cAMP) and inhibitor (brefeldin) on the release of CAs (Rocher et al., 2009). Specifically, 8-pCPT$2^{\prime}$-O-Me-cAMP reversed the action of SQ22536 and brefeldin inhibited CA-secretion during hypoxia by approximately $50 \%$. These authors suggested that the effectors of EPAC were likely to be the exocytotic machinery and $\mathrm{K}^{+}$channels (Rocher et al., 2009). More recently, this group has identified the expression of both EPAC1 and EPAC2 in the rat CB (Ramirez et al., 2012). In addition, EPAC activation by cAMP is proposed to cause downstream stimulation of the $\mathrm{IP}_{3}$ receptor in the endoplasmic reticulum (Thompson and Wyatt, 2011) along with activation of PKC (Roy et al., 2013). Thus, crosstalk between the $\mathrm{G}_{\mathrm{s}} / \mathrm{G}_{\mathrm{i}}$ (cAMPrelated) and $\mathrm{G}_{\mathrm{q}}$ signaling pathways within the type I cell likely occurs. Better characterization of this interaction could be particularly insightful given the known upregulation of $\mathrm{G}_{\mathrm{q}}$ signaling associated with $\mathrm{CB}$ dysfunction in sleep disorder breathing (Peng et al., 2006) and CHF (Li et al., 2006).

cAMP can directly bind to cyclic nucleotide-gated (CNGC) and hyperpolarization-activated cyclic nucleotide-modulated (HCNC) ion channels. These channels belong to a superfamily of voltage-gated cation channels, and thus the binding of cAMP to these channels is translated into changes in membrane potential and influx of $\mathrm{Ca}^{2+}$ and $\mathrm{Na}^{+}$. By conducting $\mathrm{Ca}^{2+}$, they can stimulate Calmodulin ( $\mathrm{CaM})$ and $\mathrm{CaM}$-dependent kinases and, in turn, modulate cAMP production by regulating activity of $\mathrm{AC}$ and PDE. Since CNGC and HCNC are also permeable to $\mathrm{Na}^{+}$ and $\mathrm{K}^{+}$, they can also alter the membrane potential in electrically active cells. The presence of these channels in the rat CB has been suggested by the work of Stea and co-workers (Stea et al., 1995); however, others have reported that cAMP analogs do not affect $\mathrm{Ca}^{2+}$ currents in type I cells (López-López et al., 1993). HCNC ion channels have not been characterized in the CB.

cAMP can be released from a variety of cell types and tissues (for a review see Bankir et al., 2002). Transport of cAMP moves against a concentration gradient, that is temperature dependent, unidirectional and requires energy (Rindler et al., 1978). One of the proposed functions of the extracellular cAMP is to regulate extracellular Ado levels. Extracellular cAMP can be metabolized by ecto-phosphodiesterases to adenosine monophosphate $\left(5^{\prime}\right.$ AMP), and then by ecto- $5^{\prime}$-nucleotidases to Ado (Conde et al., 2009). Interestingly, extracellular cAMP can modulate phenotype, function and differentiation of human monocytes through $\mathrm{A}_{2 \mathrm{~A}}$ and $\mathrm{A}_{2 \mathrm{~B}}$ Ado receptors (Sciaraffia et al., 2014). The contribution of extracellular cAMP to Ado production/Ado receptors activation has never been investigated in the $\mathrm{CB}$, and CAMP released from the $\mathrm{CB}$ has never been quantified.

Intracellular cAMP can diffuse intercellularly through wellcharacterized gap junctions (Bennett et al., 1991; Bevans et al., 1998; Bevans and Harris, 1999). In the rat CB, connexin 43 (Cx43) gap junctions are found between type I cells and carotid nerve terminals, and mediate intercellular communications and transport of small molecules and ions (Abudara and Eyzaguirre, 1996; Eyzaguirre, 2007). Electrical coupling, gap junction formation and connexin expression are regulated by cAMP (Abudara and Eyzaguirre, 1998; Abudara et al., 1999, 2000; Eyzaguirre, 2007) and chronic hypoxic exposure (Chen et al., 2002a).

All together, these findings suggest different regulations of cAMP signaling in the $\mathrm{CB}$, mediated not only by the enzymes directly involved in the synthesis and degradation of this signaling molecule, but also by a variety of effectors that can modulate its accumulation, and consequently, trigger changes in the $\mathrm{CB}$ activity.

\section{CURRENT UNDERSTANDING OF THE ROLE OF CAMP-SIGNALING PATHWAY ON THE OVERALL CAROTID BODY CHEMOSENSITIVITY}

Observations from our laboratory show that cAMP levels are higher during normoxia than in hypoxic or hyperoxic superfusate in the whole $\mathrm{CB}$ from young and adult rats (Monteiro et al., 2011). These results support our view that cAMP-pathway may be involved in the maintenance of basal activity of the CB (translated in basal release of NTs or basal CSN electrical activity), suggesting a homeostatic and/or adaptative role for the 
cAMP-pathway in the rat CB. Although, inter-species differences may exist (Delpiano and Acker, 1984, 1991; Wang et al., 1989; Pérez-García et al., 1990; Cachero et al., 1996; Chen et al., 1997). Findings from experiments studying NTs systems using CB from rabbits vs rat and cat often differ. For example, dopaminergic influence on $\mathrm{CB}$ function is excitatory in the rabbit while it is inhibitory in $\mathrm{CB}$ from other mammalian species (Fidone et al., 1982; Vicario et al., 2000a), with higher DA secretion in rats, combined with lower cAMP accumulation (through $\mathrm{D}_{2}$ receptor activity).

Together with the other reported actions of cAMP signaling in the $\mathrm{CB}$ (Table 3), our results are consistent with the view that the cAMP-pathway is involved in the maintenance of basal $\mathrm{CB}$ excitability and thus the basal release of NTs and CSN sensory discharge frequency. The observed reduction in hypoxic sensitivity when cAMP signaling is targeted indicates that basal levels of cAMP act to prime the $\mathrm{CB}$ to subsequent hypoxic stimulation. This is likely achieved through the basal regulation of PKA and EPAC and possibility other, as yet unidentified downstream effectors. Given the synergy between hypoxia and hypercapnia, the basal type I cell $[\mathrm{cAMP}]_{\mathrm{i}}$ may also confer the excitability to high $\mathrm{CO}_{2}$ or $\mathrm{H}^{+}$although further evidence is required to confirm this. It would be of considerable interest and relevant to humans to determine how chronic hyperoxia and/or hypercapnia modifies cAMP signaling in the CB.

\section{NOVEL TECHNIQUES TO STUDY CAMP SIGNALING IN THE CAROTID BODY}

With tmACs restricted to membranes, and sAC, PDEs and cAMP effectors widely distributed within the cells, cAMP accumulation is spatially and temporally controlled, generating cAMP microdomains. Thus, a comprehensive study of cAMP signaling should complement the cAMP quantifications made in $\mathrm{CB}$ homogenates using RIA (Pérez-García et al., 1991; Wang et al., 1991a; Cachero et al., 1996) or EIA (Batuca et al., 2003; Conde et al., 2008; Nunes et al., 2010, 2013; Monteiro et al., 2011), which are themselves static and terminal assays. Measurements in intact type I cells using reporter protein constructs may allow for a more detailed quantification of cAMP in distinct subcellular compartments. Nowadays, a variety of FRET-based biosensors are available to visualize signaling dynamics in living cells (Sample et al., 2014). The literature is void of data obtained using life imaging techniques to manipulate cAMP in the CB. Our laboratory in collaboration with the laboratory of Dr. Jin Zhang, have been successful in using FRET-based reporters in CB type I cells to interrogate cAMP-signaling pathways (Nunes et al., 2013).

Table 3 | Effects mediated by cAMP signaling in the carotid body.

\begin{tabular}{|c|c|c|c|c|}
\hline Effects mediated by cAMP & Preparation & Technique & Agents that modulate [cAMP] & References \\
\hline $\begin{array}{l}\text { Increase of the tyrosine } \\
\text { hydroxylase gene expression } \\
\text { elicited by hypoxia }\end{array}$ & Whole CB (adult rats) & $\begin{array}{l}\text { Reverse-Transcriptase- } \\
\text { polymerase chain reaction }\end{array}$ & FSK (0.01 mM, $3 \mathrm{~h})$ & Chen et al., 1995 \\
\hline $\begin{array}{l}\text { Increase of } \mathrm{Na}^{+} \text {and } \mathrm{Ca}^{2+} \text { inward } \\
\text { currents and capacitance }\end{array}$ & Type I cells (P5-12 rats) & $\begin{array}{l}\text { Patch-clamp/whole-cell } \\
\text { recording }\end{array}$ & $\begin{array}{l}\text { dB-cAMP }(0.2-1 \mathrm{mM}) \text { and FSK } \\
(0.01 \mathrm{mM}) \text { up to } 15 \text { days }\end{array}$ & Stea et al., 1995 \\
\hline $\begin{array}{l}\text { Induction of } \mathrm{Na}^{+} \text {- channels and } \\
\text { hypertrophy of type I cells }\end{array}$ & Type I cells (P5-12 rat) & $\begin{array}{l}\text { Patch-clamp/whole-cell } \\
\text { recording }\end{array}$ & Bt2-cAMP (1 mM, upto 14 days) & Stea et al., 1992 \\
\hline $\begin{array}{l}\text { Increase of DA release elicited by } \\
\text { hypoxia }\left(5 \% \mathrm{O}_{2}\right)\end{array}$ & Whole CB (adult rabbit) & CA release & $\begin{array}{l}\text { FSK }(5-10 \mu \mathrm{M}), \mathrm{dB}-\mathrm{cAMP}(2 \mathrm{mM}) \\
\text { IBMX }(0.5 \mathrm{mM}), \text { ISO } \\
(0.01-0.050 \mathrm{mM})\end{array}$ & $\begin{array}{l}\text { Pérez-García et al., } \\
\text { 1990, 1991, } 1993\end{array}$ \\
\hline $\begin{array}{l}\text { Elevation of } \mathrm{Ca}^{2+} \text { - currents } \\
\text { (mimic the effect of hypercapnia) }\end{array}$ & Type I cells (adult rabbit) & Whole-cell recording & 8-Br-cAMP (0.5 mM, $10 \mathrm{~min})$ & $\begin{array}{l}\text { Summers et al., } \\
2002\end{array}$ \\
\hline $\begin{array}{l}\text { Increase of GAP-43 and } \\
\text { neurofilament (NF68 and NF160 } \\
\text { kD) expression and neurite } \\
\text { outgrowth }\end{array}$ & Type I cells (P5-7 rat) & $\begin{array}{l}\text { Double-label immunofluore } \\
\text { scence }\end{array}$ & $\begin{array}{l}\mathrm{dB}-\mathrm{cAMP}(1 \mathrm{mM}) \text {, FSK }(0.01 \mathrm{mM}) \text {, } \\
\text { up to } 2 \text { weeks }\end{array}$ & $\begin{array}{l}\text { Jackson and Nurse, } \\
1995\end{array}$ \\
\hline
\end{tabular}

dB-cAMP or Bt2-CAMP, Dibutyryl-cAMP; 8-Br-CAMP, 8-Bromoadenosine-cAMP; FSK, Forskolin; P, Postnatal day; CA, catecholamines; CSN, Carotid Sinus Nerve; DA, Dopamine; ISO, Isoprostane; IBMX, Isobutyl-1-methylxanthine; GAP-43, Growth-Associated Protein 43; CB, carotid body. 
Image-based techniques can be used to understand interactions between cAMP and other mediators that raise $\left[\mathrm{Ca}^{2+}\right]_{\mathrm{i}}$ levels. Intensification of $\left[\mathrm{Ca}^{2+}\right]_{i}$ signals have been linked with raised levels of angiotensin II, endothelin-1, cytokines, insulin and free radicals along with decreases in nitric oxide: levels of these substances are changed in disease states, associated with CB dysfunction (Chen et al., 2002b; Rey et al., 2006; Fung et al., 2007; Li et al., 2010; Schultz, 2011; Del Rio et al., 2012; Lam et al., 2012; Ribeiro et al., 2013). Intracellular $\mathrm{Ca}^{2+}$ levels can influence cAMP signaling directly through modulation of the activity of $\mathrm{PDE}$ and $\mathrm{AC}$ isoforms or indirectly through $\mathrm{PKC}$ activity, not only by allosteric regulation, but also by desensitization of GPCRs. In this sense, a compensatory cAMP mechanism may function to partially restore some sort of homeostatic control within the type I cell despite serious remodeling of the sensory transduction cascade in CB dysfunction.

As described above, our current view is that cAMP has an important role in the $\mathrm{CB}$ homeostasis, as suggested by the higher cAMP levels under normoxic conditions. Understanding how $\left[\mathrm{Ca}^{2+}\right]_{i}$ and cAMP signaling is modified in conditions that lead to $\mathrm{CB}$ dysfunction, will be fundamental to understanding the role of these second messengers in the
$\mathrm{CB}$ transduction/neurotransmission mechanism in health and disease.

\section{IS CAROTID BODY IMPLICATED IN THE EFFECTS OF DRUGS THAT MODIFY CAMP FOR THERAPEUTIC PURPOSES?}

The following section focuses on the CB mediated effects induced by currently clinical therapy that target cAMP-signaling. It is not aimed to extensively describe the putative drug effects that can be mediated by the $\mathrm{CB}$ but only to give insights that can stimulate future research in a field where the information is scarce. Figure 1 summarizes molecular targets in type I cell and CSN endings that may be affected by drugs-induced changes in CAMP accumulation.

Exogenous DA is extensively used in human to improve cardiac output and peripheral perfusion in patients with cardiogenic and septic shock. Several years after using DA, its inhibitory effects on ventilation in man were described and attributed to an effect on chemoreceptor reflexes (Welsh et al., 1978). Twenty years later, Van de Borne et al. (1998) showed that repeated use of DA impairs the ventilatory response to hypoxemia due to an inhibitory effect on CSN activity, which explains why when administered in low doses to conscious patients, DA reduces the discomfort caused by

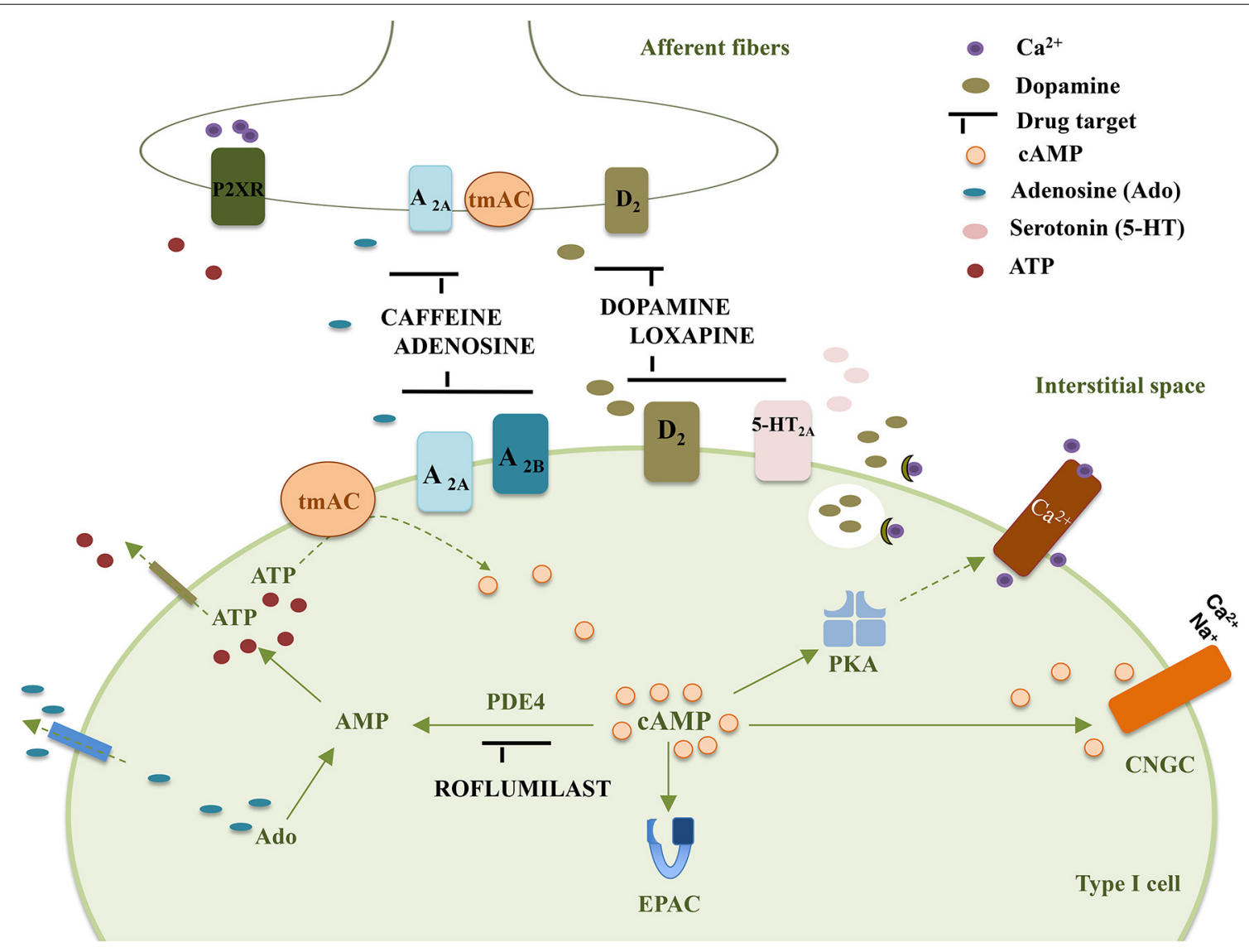

FIGURE 1|Representation of some drug targets in type I cells and CSN endings that affect cAMP accumulation in the carotid body. tmAC, transmembrane Adenylyl Cyclase; PKA, Protein Kinase A; EPAC, Exchange Protein Activated CAMP; $D_{2}$, Dopamine receptor
$D_{2} ; A_{2 A}$, Adenosine receptor $A_{2 A} ; A_{2 B}$, Adenosine receptor $A_{2 B}$; $5-\mathrm{HT}_{2 \mathrm{~A}}$, serotonin receptor $5-\mathrm{HT}_{2 \mathrm{~A}} ; \mathrm{P} 2 \mathrm{XR}$, ATP ionotropic $\mathrm{P} 2 \mathrm{X}$ receptor; Ado, adenosine; PDE4, Phosphodiesterase 4; CNGC, Cyclic Nucleotide Gated channel. 
hypoxemia. Although its clinical use as vasopressor remains, both DA and NA have been used: DA decreases CB activity while NA does not appear to have an effect on CB activity (Zapata, 1975; Debaveye and Van den Berghe, 2004).

The impact of chronic use of antipsychotics ( $\mathrm{D}_{2}$ antagonists) on peripheral chemoreflexes is unknown but beneficial effects of loxapine on agitation and breathing patterns during weaning from mechanic ventilation have been described (Sztrymf et al., 2010). These findings open doors to a promising field to explore CB manipulation to improve adaptation to mechanical ventilation.

Acute administration of Ado (full agonist of $\mathrm{A}_{2 \mathrm{~A}}$ and $\mathrm{A}_{2 \mathrm{~B}}$ receptors) is clinically useful to revert paroxysmal supraventricular tachycardia and causes dyspnea and chest discomfort mediated by CB activation (Watt et al., 1987; Reid et al., 1991). Caffeine is a non-selective Ado antagonist that has been used to prevent and treat apnea of prematurity due, primarily, to the blockade of inhibitory Ado $A_{1}$ receptors in the CNS. Moreover, the effects of chronic coffee consumption have been extensively studied in the last years and it is now consensual that coffee, and probably caffeine, may reduce the risk of type 2 diabetes mellitus and hypertension, as well as other conditions associated with cardiovascular risk such as obesity and depression (O'Keefe et al., 2013). In fact, research in our laboratory have shown that chronic caffeine intake decreases circulating CAs, prevents diet-induced insulin resistance and hypertension (Conde et al., 2012b) and restores insulin sensitivity in aged rats (Guarino et al., 2013). Knowing that at the $\mathrm{CB}$, caffeine blocks excitatory Ado $\mathrm{A}_{2 \mathrm{~A}} / \mathrm{A}_{2 \mathrm{~B}}$ receptors (Conde et al., 2006b) and that $\mathrm{CB}$ denervation prevents the development of insulin resistance and hypertension induced by hypercaloric diets (Ribeiro et al., 2013) the CB modulation by caffeine can improve conditions associated to sympathetic mediated CB hyperactivity (e.g., hypertension). Other effects of caffeine have been described in the CB e.g., mobilization of $\mathrm{Ca}_{i}^{2+}$ stores in the $\mathrm{CB}$ cells by ryanodine receptor activation (Vicario et al., 2000b; Mokashi et al., 2001). However, they do not seem to be relevant in the clinical setting because their effects are achieved with toxic concentrations (Fredholm et al., 1999).

Roflumilast, an oral selective PDE4 inhibitor, was approved in 2011 by both the Food and Drug Administration (FDA) and the European Medicines Agency (EMA) for the treatment of severe chronic obstructive pulmonary disease (COPD), due to its anti-inflammatory and bronchodilator effects. No evidences of roflumilast effects on $\mathrm{CB}$ activity have been reported and those are difficult to address essentially because of their CNS effects and the variability of the PDE inhibitors efficacy in hypoxic conditions (Nunes et al., 2010). Curiously, the roflumilast efficacy to reduce the risk of COPD exacerbations has only been shown in patients that experience reduced dyspnea (Rennard et al., 2014). Since CB resection relieves dyspnea in COPD patients and improves $\mathrm{FEV}_{1}$ (Force Expiratory Volume) (Whipp and Ward, 1992) but exarcebates hypoxemia and hypercapnia and overall worsen the long term outcome (Stulbarg et al., 1989), the link between the mechanism of roflumilast action in COPD patients and $\mathrm{CB}$ activity merits further studies.

From the above evidence, one can conclude that the manipulation of cAMP signaling pathway is important to address $\mathrm{O}_{2} / \mathrm{CO}_{2}$ related diseases. However, manipulation of cAMP signaling may have consequences in the $\mathrm{CB}$, that are clinically relevant and that have not yet been identified.

\section{CONCLUSIONS}

The importance of cAMP to CB physiology has moved from a discarded player in the $\mathrm{O}_{2}$ chemotransduction to a central signaling molecule that is converged upon by multiple NTs/NMs, which collectively maintain an equilibrated $\mathrm{CB}$ activity. It remains to be seen whether modification of cAMP can improve patient outcomes in diseases associated with $\mathrm{CB}$ impairment or hyperactivity. We suggest that cAMP has an important role in the homeostasis of the CB since CAMP levels seem to be higher under normoxic conditions. Despite the increase in knowledge of $\mathrm{CB}$ physiology, the activity of tyrosine hydroxylase is still the hallmark of the CB and CAMP the classical second messenger of dopamine $\mathrm{D}_{2}$ receptor signaling.

Understanding how calcium and cAMP cooperate in dysfunction $\mathrm{CB}$, will be fundamental to understand the role of these second messengers in the $\mathrm{CB}$ transduction mechanism. Additionally, systemic pharmacological manipulation of cAMP signaling can have clinically relevant consequences mediated by the $\mathrm{CB}$. This may proven to be an exciting field of research that is still currently unexplored.

\section{ACKNOWLEDGMENT}

This study was funded by an operating grant PTDC/SAUTOX/112264/2009.

\section{REFERENCES}

Abdala, A. P., McBryde, F. D., Marina, N., Hendy, E. B., Engelman, Z. J., Fudim, M., et al. (2012). Hypertension is critically dependent on the carotid body input in the spontaneously hypertensive rat. J. Physiol. 590, 4269-4277. doi: 10.1113/jphysiol.2012.237800

Abdel-Halim, S. M., Guenifi, A., He, B., Yang, B., Mustafa, M., Höjeberg, B., et al. (1998). Mutations in the promoter of adenylyl cyclase (AC)-III gene, overexpression of AC-III mRNA, and enhanced cAMP generation in islets from the spontaneously diabetic GK rat model of type 2 diabetes. Diabetes 47, 498-504. doi: 10.2337/diabetes.47.3.498

Abudara, V., and Eyzaguirre, C. (1996). Reflections on the carotid nerve sensory discharge and coupling between glomus cells. Adv. Exp. Med. Biol. 410, 159-167. doi: 10.1007/978-1-4615-5891-0_23

Abudara, V., and Eyzaguirre, C. (1998). Modulation of junctional conductance between rat carotid body glomus cells by hypoxia, cAMP and acidity. Brain Res. 792, 114-125. doi: 10.1016/S0006-8993(98)00127-9

Abudara, V., Eyzaguirre, C., and Sáez, J. C. (2000). Short- and long-term regulation of rat carotid body gap junctions by cAMP. Identification of connexin43, a gap junction subunit. Adv. Exp. Med. Biol. 475, 359-369. doi: 10.1007/0-30646825-5_33

Abudara, V., Garcés, G., and Sáez, J. C. (1999). Cells of the carotid body express connexin 43 which is up-regulated by cAMP. Brain Res. 849, 25-33. doi: 10.1016/S0006-8993(99)01946-0

Alcayaga, C., Varas, R., Valdés, V., Cerpa, V., Arroyo, J., Iturriaga, R., et al. (2007). ATP- and ACh-induced responses in isolated cat petrosal ganglion neurons. Brain Res. 1131, 60-67. doi: 10.1016/j.brainres.2006.11.012

Alcayaga, J., Iturriaga, R., Varas, R., Arroyo, J., and Zapata, P. (1998). Selective activation of carotid nerve fibers by acetylcholine applied to the cat petrosal ganglion in vitro. Brain Res. 786, 47-54. doi: 10.1016/S0006-8993(97) 01424-8

Almaraz, L., Pérez-García, M. T., Gómez-Nino, A., and González, C. (1997). Mechanisms of alpha2-adrenoceptor-mediated inhibition in rabbit carotid body. Am. J. Physiol. 272, C628-C637. 
Almaraz, L., Pérez-García, M. T., and González, C. (1991). Presence of D1 receptors in the rabbit carotid body. Neurosci. Lett. 132, 259-262. doi: 10.1016/03043940(91)90315-K

Bairam, A., Frenette, J., Dauphin, C., Carroll, J. L., and Khandjian, E. W. (1998). Expression of dopamine D1-receptor mRNA in the carotid body of adult rabbits, cats and rats. Neurosci. Res. 31, 147-154. doi: 10.1016/S01680102(98)00033-9

Bairam, A., Joseph, V., Lajeunesse, Y., and Kinkead, R. (2006). Developmental pattern of M1 and M2 muscarinic gene expression and receptor levels in cat carotid body, petrosal and superior cervical ganglion. Neuroscience 139, 711-721. doi: 10.1016/j.neuroscience.2005.12.030

Bairam, A., Joseph, V., Lajeunesse, Y., and Kinkead, R. (2007). Developmental profile of cholinergic and purinergic traits and receptors in peripheral chemoreflex pathway in cats. Neuroscience 146, 1841-1853. doi: 10.1016/j.neuroscience.2007.03.034

Bairam, A., and Khandjian, E. W. (1997). Expression of dopamine D2 receptor mRNA isoforms in the carotid body of rat, cat and rabbit. Brain Res. 760, 287-289. doi: 10.1016/S0006-8993(97)00399-5

Bankir, L., Ahloulay, M., Devreotes, P. N., and Parent, C. A. (2002). Extracellular cAMP inhibits proximal reabsorption: are plasma membrane cAMP receptors involved? Am. J. Physiol. Renal Physiol. 282, F376-F392. doi: 10.1152/ajprenal. 00202.2001

Batuca, J. R., Monteiro, T. C., and Monteiro, E. C. (2003). Contribution of dopamine D2 receptors for the cAMP levels at the carotid body. Adv. Exp. Med. Biol. 536, 367-373. doi: 10.1007/978-1-4419-9280-2_48

Beene, D. L., and Scott, J. D. (2007). A-kinase anchoring proteins take shape. Curr. Opin. Cell Biol. 19, 192-198. doi: 10.1016/j.ceb.2007.02.011

Bender, A. T., and Beavo, J. A. (2006). Cyclic nucleotide phosphodiesterases: molecular regulation to clinical use. Pharmacol. Rev. 58, 488-520. doi: 10.1124/pr.58.3.5

Bennett, M. V., Barrio, L. C., Bargiello, T. A., Spray, D. C., Hertzberg, E., and Sáez, J. C. (1991). Gap junctions: new tools, new answers, new questions. Neuron 6, 305-320. doi: 10.1016/0896-6273(91)90241-Q

Benot, A. R., and López-Barneo, J. (1990). Feedback Inhibition of Ca2+ currents by dopamine in glomus cells of the carotid body. Eur. J. Neurosci. 2, 809-812. doi: 10.1111/j.1460-9568.1990.tb00473.x

Bevans, C. G., and Harris, A. L. (1999). Direct high affinity modulation of connexin channel activity by cyclic nucleotides. J. Biol. Chem. 274, 3720-3725. doi: 10.1074/jbc.274.6.3720

Bevans, C. G., Kordel, M., Rhee, S. K., and Harris, A. L. (1998). Isoform composition of connexin channels determines selectivity among second messengers and uncharged molecules. J. Biol. Chem. 273, 2808-2816. doi: 10.1074/jbc. 273.5.2808

Buck, J., Sinclair, M. L., Schapal, L., Cann, M. J., and Levin, L. R. (1999). Cytosolic adenylyl cyclase defines a unique signaling molecule in mammals. Proc. Natl. Acad. Sci. U.S.A. 96, 79-84. doi: 10.1073/pnas.96.1.79

Cachero, T. G., Rigual, R., Rocher, A., and Gonzalez, C. (1996). Cholera and pertussis toxins reveal multiple regulation of cAMP levels in the rabbit carotid body. Eur. J. Neurosci. 8, 2320-2327. doi: 10.1111/j.1460-9568.1996.tb01195.x

Campanucci, V. A., Dookhoo, L., Vollmer, C., and Nurse, C. A. (2012). Modulation of the carotid body sensory discharge by NO: an up-dated hypothesis. Respir. Physiol. Neurobiol. 184, 149-157. doi: 10.1016/j.resp.2012.04.005

Carpenter, E., and Peers, C. (1997). Swelling- and cAMP-activated Cl- currents in isolated rat carotid body type I cells. J. Physiol. 503(Pt 3), 497-511. doi: 10.1111/j.1469-7793.1997.497bg.x

Carroll, J. L., Boyle, K. M., Wasicko, M. J., and Sterni, L. M. (2005). Dopamine D2 receptor modulation of carotid body type 1 cell intracellular calcium in developing rats. Am. J. Physiol. Lung Cell. Mol. Physiol. 288, L910-L916. doi: 10.1152/ajplung.00414.2003

Chen, J., Dinger, B., and Fidone, S. J. (1997). cAMP production in rabbit carotid body: role of adenosine carotid bodies CAMP production in rabbit carotid body: role of adenosine. J. Appl. Physiol. 82, 1771-1775.

Chen, J., Dinger, B., and Fidone, S. J. J. (1995). Second messenger regulation of tyrosine hydroxylase gene expression in rat carotid body. Neurosignals 4, 277-285. doi: $10.1159 / 000109453$

Chen, J., He, L., Dinger, B., Stensaas, L., and Fidone, S. (2002a). Chronic hypoxia upregulates connexin 43 expression in rat carotid body and petrosal ganglion. J. Appl. Physiol. 92, 1480-1486.
Chen, Y., Cann, M. J., Litvin, T. N., Iourgenko, V., Sinclair, M. L., Levin, L. R., et al. (2000). Soluble adenylyl cyclase as an evolutionarily conserved bicarbonate sensor. Science 289, 625-628. doi: 10.1126/science.289.5479.625

Chen, Y., Tipoe, G. L., Liong, E., Leung, S., Lam, S.-Y., Iwase, R., et al. (2002b). Chronic hypoxia enhances endothelin-1-induced intracellular calcium elevation in rat carotid body chemoreceptors and up-regulates ETA receptor expression. Pflugers Arch. 443, 565-573. doi: 10.1007/s00424-001-0728-2

Conde, S. V., Gonzalez, C., Batuca, J. R., Monteiro, E. C., and Obeso, A. (2008). An antagonistic interaction between $\mathrm{A} 2 \mathrm{~B}$ adenosine and D2 dopamine receptors modulates the function of rat carotid body chemoreceptor cells. J. Neurochem. 107, 1369-1381. doi: 10.1111/j.1471-4159.2008.05704.x

Conde, S. V., and Monteiro, E. C. (2004). Hypoxia induces adenosine release from the rat carotid body. J. Neurochem. 89, 1148-1156. doi: 10.1111/j.14714159.2004.02380.x

Conde, S. V., and Monteiro, E. C. (2006a). Activation of nicotinic ACh receptors with alpha4 subunits induces adenosine release at the rat carotid body. $\mathrm{Br}$. J. Pharmacol. 147, 783-789. doi: 10.1038/sj.bjp.0706676

Conde, S. V., Monteiro, E. C., Obeso, A., and Gonzalez, C. (2009). Adenosine in peripheral chemoreception: new insights into a historically overlooked molecule-invited article. Adv. Exp. Med. Biol. 648, 145-159. doi: 10.1007/97890-481-2259-2_17

Conde, S. V., Monteiro, E. C., Rigual, R., Obeso, A., and Gonzalez, C. (2012a). Hypoxic intensity: a determinant for the contribution of ATP and adenosine to the genesis of carotid body chemosensory activity. J. Appl. Physiol. 112, 2002-2010. doi: 10.1152/japplphysiol.01617.2011

Conde, S. V., Nunes da Silva, T., Gonzalez, C., Mota Carmo, M., Monteiro, E. C., and Guarino, M. P. (2012b). Chronic caffeine intake decreases circulating catecholamines and prevents diet-induced insulin resistance and hypertension in rats. Br. J. Nutr. 107, 86-95. doi: 10.1017/S0007114511002406

Conde, S. V., Obeso, A., Vicario, I., Rigual, R., Rocher, A., and Gonzalez, C. (2006b). Caffeine inhibition of rat carotid body chemoreceptors is mediated by A2A and A2B adenosine receptors. J. Neurochem. 98, 616-628. doi: 10.1111/j.1471-4159.2006.03912.x

Cook, Z. C., Gray, M. A., and Cann, M. J. (2012). Elevated carbon dioxide blunts mammalian cAMP signaling dependent on inositol 1,4,5-triphosphate receptor-mediated $\mathrm{Ca} 2+$ release. J. Biol. Chem. 287, 26291-26301. doi: 10.1074/jbc.M112.349191

Craven, K. B., and Zagotta, W. N. (2006). CNG and HCN channels: two peas, one pod. Annu. Rev. Physiol. 68, 375-401. doi: 10.1146/annurev.physiol.68. 040104.134728

Czyzyk-Krzeska, M. F., Lawson, E. E., and Millhorn, D. E. (1992). Expression of D2 dopamine receptor mRNA in the arterial chemoreceptor afferent pathway. J. Auton. Nerv. Syst. 41, 31-39. doi: 10.1016/0165-1838(92)90124-Y

Daly, J. W., Hide, I., Müller, C. E., and Shamim, M. (1991). Caffeine analogs: structure-activity relationships at adenosine receptors. Pharmacology 42, 309-321. doi: 10.1159/000138813

Debaveye, Y. A., and Van den Berghe, G. H. (2004). Is there still a place for dopamine in the modern intensive care unit? Anesth. Analg. 98, 461-468. doi: 10.1213/01.ANE.0000096188.35789.37

Deighan, C., Methven, L., Naghadeh, M. M., Wokoma, A., Macmillan, J., Daly, C. J., et al. (2005). Insights into the functional roles of alpha(1)-adrenoceptor subtypes in mouse carotid arteries using knockout mice. Br. J. Pharmacol. 144, 558-565. doi: 10.1038/sj.bjp.0706089

Delpiano, M. A., and Acker, H. (1984). O2 chemoreception of the cat carotid body in vitro. Adv. Exp. Med. Biol. 169, 705-717. doi: 10.1007/978-1-4684-1188-1_63

Delpiano, M. A., and Acker, H. (1991). Hypoxia increases the cyclic AMP content of the cat carotid body in vitro. J. Neurochem. 57, 291-297. doi: 10.1111/j.14714159.1991.tb02127.x

Delpiano, M. A., Starlinger, H., Fischer, M., and Acker, H. (1984). "The cAMP content of the carotid body in vivo and in vitro under normoxia and after stimulation by hypoxia," in The Peripheral Arterial Chemoreceptors, ed J. PallotD (London: Croom Helm), 401-408.

Del Rio, R., Moya, E. A., Alcayaga, J., and Iturriaga, R. (2009). Evidence for histamine as a new modulator of carotid body chemoreception. Adv. Exp. Med. Biol. 648, 177-184. doi: 10.1007/978-90-481-2259-2_20

Del Rio, R., Moya, E. A., Koenig, C. S., Fujiwara, K., Alcayaga, J., and Iturriaga, R. (2008). Modulatory effects of histamine on cat carotid body chemoreception. Respir. Physiol. Neurobiol. 164, 401-410. doi: 10.1016/j.resp.2008.09.005 
Del Rio, R., Moya, E. A., Parga, M. J., Madrid, C., and Iturriaga, R. (2012). Carotid body inflammation and cardiorespiratory alterations in intermittent hypoxia. Eur. Respir. J. 39, 1492-1500. doi: 10.1183/09031936.00141511

De Rooij, J., Zwartkruis, F. J., Verheijen, M. H., Cool, R. H., Nijman, S. M., Wittinghofer, A., et al. (1998). Epac is a Rapl guanine-nucleotide-exchange factor directly activated by cyclic AMP. Nature 396, 474-477. doi: 10.1038/24884

Dinger, B. G., Almaraz, L., Hirano, T., Yoshizaki, K., Gonzalez, C., Gomez-Niño, A., et al. (1991). Muscarinic receptor localization and function in rabbit carotid body. Brain Res. 562, 190-198.

Dinger, B., Gonzalez, C., Yoshizaki, K., and Fidone, S. (1981a). [3H]Spiroperidol binding in normal and denervated carotid bodies. Neurosci. Lett. 21, 51-55. doi: 10.1016/0304-3940(81)90056-2

Dinger, B., Gonzalez, C., Yoshizaki, K., and Fidone, S. (1981b). Alpha-bungarotoxin binding in cat carotid body. Brain Res. 205, 187-193. doi: 10.1016/00068993(81)90731-9

Dousa, T. P. (1999). Cyclic- $3^{\prime}, 5^{\prime}$-nucleotide phosphodiesterase isozymes in cell biology and pathophysiology of the kidney. Kidney Int. 55, 29-62. doi: 10.1046/j.1523-1755.1999.00233.x

Eyzaguirre, C. (2007). Electric synapses in the carotid body-nerve complex. Respir. Physiol. Neurobiol. 157, 116-122. doi: 10.1016/j.resp.2007.01.013

Eyzaguirre, C., Koyano, H., and Taylor, J. R. (1965). Presence of acetylcholine and transmitter release from carotid body chemoreceptors. J. Physiol. 178, 463-476.

Fagerlund, M. J., Kåhlin, J., Ebberyd, A., Schulte, G., Mkrtchian, S., and Eriksson, L. I. (2010). The human carotid body: expression of oxygen sensing and signaling genes of relevance for anesthesia. Anesthesiology 113, 1270-1279. doi: 10.1097/ALN.0b013e3181fac061

Fearon, I. M., Zhang, M., Vollmer, C., and Nurse, C. A. (2003). GABA mediates autoreceptor feedback inhibition in the rat carotid body via presynaptic GABAB receptors and TASK-1. J. Physiol. 553, 83-94. doi: 10.1113/jphysiol.2003. 048298

Fernández, R., Nardocci, G., Simon, F., Martin, A., Becerra, A., Rodríguez-Tirado, C., et al. (2011). Lipopolysaccharide signaling in the carotid chemoreceptor pathway of rats with sepsis syndrome. Respir. Physiol. Neurobiol. 175, 336-348. doi: 10.1016/j.resp.2010.12.014

Fidone, S., Gonzales, C., Dinger, B., and Stensaas, L. (1990). "Transmitter dynamics in the carotid body," in Chemoreceptors and Chemoreceptor Reflexes SE 1, eds H. Acker, A. Trzebski, and R. O’Regan (Salt Lake: Springer), 3-14. doi: 10.1007/978-1-4684-8938-5_1

Fidone, S., Gonzalez, C., and Yoshizaki, K. (1982). Effects of low oxygen on the release of dopamine from the rabbit carotid body in vitro. J. Physiol. 333, 93-110

Fitzgerald, R. S., Rogus, E. M., and Dehghani, A. (1977). Catecholamines and 3',5' cyclic AMP in carotid body chemoreception in the cat. Adv. Exp. Med. Biol. 78, 245-258. doi: 10.1007/978-1-4615-9035-4_20

Folgering, H., Ponte, J., and Sadig, T. (1982). Adrenergic mechanisms and chemoreception in the carotid body of the cat and rabbit. J. Physiol. 325, 1-21.

Fredholm, B. B., Bättig, K., Holmén, J., Nehlig, A., and Zvartau, E. E. (1999). Actions of caffeine in the brain with special reference to factors that contribute to its widespread use. Pharmacol. Rev. 51, 83-133.

Fung, M. L., Lam, S. Y., Chen, Y., Dong, X., and Leung, P. S. (2001). Functional expression of angiotensin II receptors in type-I cells of the rat carotid body. Pflugers Arch. 441, 474-480. doi: 10.1007/s004240000445

Fung, M.-L., Lam, S.-Y., Wong, T.-P., Tjong, Y.-W., and Leung, P.-S. (2007). Carotid body AT(4) receptor expression and its upregulation in chronic hypoxia. Open Cardiovasc. Med. J. 1, 1-7. doi: 10.2174/1874192400701010001

Gauda, E. B. (2002). Gene expression in peripheral arterial chemoreceptors. Microsc. Res. Tech. 59, 153-167. doi: 10.1002/jemt.10190

Gloerich, M., and Bos, J. L. (2010). Epac: defining a new mechanism for cAMP action. Annu. Rev. Pharmacol. Toxicol. 50, 355-375. doi: 10.1146/annurev.pharmtox.010909.105714

Gonzalez, C., and Fidone, S. (1977). Increased release of [(3)H]dopamine during low $\mathrm{O}(2)$ stimulation of rabbit carotid body in vitro. Neurosci. Lett. 6, 95-99. doi: 10.1016/0304-3940(77)90002-7

Guarino, M. P., Ribeiro, M. J., Sacramento, J. F., and Conde, S. V. (2013). Chronic caffeine intake reverses age-induced insulin resistance in the rat: effect on skeletal muscle Glut4 transporters and AMPK activity. Age (Dordr). 35, 1755-1765. doi: 10.1007/s11357-012-9475-x

Halls, M. L., and Cooper, D. M. F. (2011). Regulation by Ca2+-signaling pathways of adenylyl cyclases. Cold Spring Harb. Perspect. Biol. 3:a004143. doi: 10.1101/cshperspect.a004143
Hanbauer, I., and Lovenberg, W. (1977). Presence of a calcium2+-dependent activator of cyclic-nucleotide phosphodiesterase in rat carotid body: effects of hypoxia. Neuroscience 2, 603-607. doi: 10.1016/0306-4522(77)90057-4

Hatton, C. J., and Peers, C. (1996). Cyclic nucleotide analogs do not interfere with hypoxic inhibition of $\mathrm{K}+$ currents in isolated rat type I carotid body cells. $A d v$. Exp. Med. Biol. 410, 93-96. doi: 10.1007/978-1-4615-5891-0_13

Hauton, D., Holmes, A., Ziff, O., and Kumar, P. (2013). The impact of acute and chronic catecholamines on respiratory responses to hypoxic stress in the rat. Pflugers Arch. 465, 209-219. doi: 10.1007/s00424-012-1210-Z

He, L., Dinger, B., and Fidone, S. (2005). Effect of chronic hypoxia on cholinergic chemotransmission in rat carotid body. J. Appl. Physiol. 98, 614-619. doi: 10.1152/japplphysiol.00714.2004

Hess, K. C., Jones, B. H., Marquez, B., Chen, Y., Ord, T. S., Kamenetsky, M., et al. (2005). The "soluble" adenylyl cyclase in sperm mediates multiple signaling events required for fertilization. Dev. Cell 9, 249-259. doi: 10.1016/j.devcel.2005.06.007

Hodges, G. J., Gros, R., Hegele, R. A., Van Uum, S., Shoemaker, J. K., and Feldman, R. D. (2010). Increased blood pressure and hyperdynamic cardiovascular responses in carriers of a common hyperfunctional variant of adenylyl cyclase 6. J. Pharmacol. Exp. Ther. 335, 451-457. doi: 10.1124/jpet.110. 172700

Hofer, A. M., and Lefkimmiatis, K. (2007). Extracellular calcium and cAMP: second messengers as "third messengers"? Physiology (Bethesda) 22, 320-327. doi: 10.1152/physiol.00019.2007

Holz, G. G., Kang, G., Harbeck, M., Roe, M. W., and Chepurny, O. G. (2006). Cell physiology of cAMP sensor Epac. J. Physiol. 577, 5-15. doi: 10.1113/jphysiol.2006.119644

Igarashi, A., Zadzilka, N., and Shirahata, M. (2009). Benzodiazepines and GABAGABAA receptor system in the cat carotid body. Adv. Exp. Med. Biol. 648, 169-175. doi: 10.1007/978-90-481-2259-2_19

Iturriaga, R., Alcayaga, J., and Gonzalez, C. (2009). Neurotransmitters in carotid body function: the case of dopamine-invited article. Adv. Exp. Med. Biol. 648, 137-143. doi: 10.1007/978-90-481-2259-2_16

Iturriaga, R., Cerpa, V., Zapata, P., and Alcayaga, J. (2003). Catecholamine release from isolated sensory neurons of cat petrosal ganglia in tissue culture. Brain Res. 984, 104-110. doi: 10.1016/S0006-8993(03)03118-4

Jackson, A., and Nurse, C. (1995). Plasticity in cultured carotid body chemoreceptors: environmental modulation of GAP-43 and neurofilament. J. Neurobiol. 26, 485-496. doi: 10.1002/neu.480260403

Jaiswal, B. S., and Conti, M. (2003). Calcium regulation of the soluble adenylyl cyclase expressed in mammalian spermatozoa. Proc. Natl. Acad. Sci. U.S.A. 100, 10676-10681. doi: 10.1073/pnas.1831008100

Kåhlin, J., Eriksson, L. I., Ebberyd, A., and Fagerlund, M. J. (2010). Presence of nicotinic, purinergic and dopaminergic receptors and the TASK-1 K+channel in the mouse carotid body. Respir. Physiol. Neurobiol. 172, 122-128. doi: 10.1016/j.resp.2010.05.001

Kamenetsky, M., Middelhaufe, S., Bank, E. M., Levin, L. R., Buck, J., and Steegborn, C. (2006). Molecular details of cAMP generation in mammalian cells: a tale of two systems. J. Mol. Biol. 362, 623-639. doi: 10.1016/j.jmb.2006.07.045

Katz, D. M., and Black, I. B. (1986). Expression and regulation of catecholaminergic traits in primary sensory neurons: relationship to target innervation in vivo. J. Neurosci. 6, 983-989.

Katz, D. M., Markey, K. A., Goldstein, M., and Black, I. B. (1983). Expression of catecholaminergic characteristics by primary sensory neurons in the normal adult rat in vivo. Proc. Natl. Acad. Sci. U.S.A. 80, 3526-3530. doi: 10.1073/pnas.80.11.3526

Kobayashi, S., Conforti, L., and Millhorn, D. E. (2000). Gene expression and function of adenosine A(2A) receptor in the rat carotid body. Am. J. Physiol. Lung Cell. Mol. Physiol. 279, L273-L282

Kou, Y. R., Ernsberger, P., Cragg, P. A., Cherniack, N. S., and Prabhakar, N. R. (1991). Role of alpha 2-adrenergic receptors in the carotid body response to isocapnic hypoxia. Respir. Physiol. 83, 353-364. doi: 10.1016/0034-5687(91) 90054-M

Lam, S.-Y., Liu, Y., Ng, K.-M., Lau, C.-F., Liong, E. C., Tipoe, G. L., et al. (2012). Chronic intermittent hypoxia induces local inflammation of the rat carotid body via functional upregulation of proinflammatory cytokine pathways. Histochem. Cell Biol. 137, 303-317. doi: 10.1007/s00418-011-0900-5

Lam, S.-Y., Tipoe, G. L., and Fung, M. L. (2009). Upregulation of erythropoietin and its receptor expression in the rat carotid body during chronic and 
intermittent hypoxia. Adv. Exp. Med. Biol. 648, 207-214. doi: 10.1007/978-90481-2259-2_24

Lam, S.-Y., Tipoe, G. L., Liong, E. C., and Fung, M.-L. (2008). Chronic hypoxia upregulates the expression and function of proinflammatory cytokines in the rat carotid body. Histochem. Cell Biol. 130, 549-559. doi: 10.1007/s00418-008$0437-4$

Lazarov, N. E., Reindl, S., Fischer, F., and Gratzl, M. (2009). Histaminergic and dopaminergic traits in the human carotid body. Respir. Physiol. Neurobiol. 165, 131-136. doi: 10.1016/j.resp.2008.10.016

Lee, S.-D., Nakano, H., and Farkas, G. A. (2005). Adenosinergic modulation of ventilation in obese zucker rats. Obes. Res. 13, 545-555. doi: 10.1038/oby.2005.58

Li, Y.-L., Xia, X.-H., Zheng, H., Gao, L., Li, Y.-F., Liu, D., et al. (2006). Angiotensin II enhances carotid body chemoreflex control of sympathetic outflow in chronic heart failure rabbits. Cardiovasc. Res. 71, 129-138. doi: 10.1016/j.cardiores.2006.03.017

Li, Y.-L., Zheng, H., Ding, Y., and Schultz, H. D. (2010). Expression of neuronal nitric oxide synthase in rabbit carotid body glomus cells regulates large-conductance Ca2+-activated potassium currents. J. Neurophysiol. 103, 3027-3033. doi: 10.1152/jn.01138.2009

Lochner, A., and Moolman, J. A. (2006). The many faces of H89: a review. Cardiovasc. Drug Rev. 24, 261-274. doi: 10.1111/j.1527-3466.2006.00261.x

López-López, J. R., De Luis, D. A., and Gonzalez, C. (1993). Properties of a transient $\mathrm{K}+$ current in chemoreceptor cells of rabbit carotid body. J. Physiol. 460, 15-32.

Lugnier, C. (2006). Cyclic nucleotide phosphodiesterase (PDE) superfamily: a new target for the development of specific therapeutic agents. Pharmacol. Ther. 109, 366-398. doi: 10.1016/j.pharmthera.2005.07.003

Maclean, M. R., Johnston, E. D., Mcculloch, K. M., Pooley, L., Houslay, M. D., and Sweeney, G. (1997). Phosphodiesterase isoforms in the pulmonary arterial circulation of the rat: changes in pulmonary hypertension. J. Pharmacol. Exp. Ther. 283, 619-624.

McBryde, F. D., Abdala, A. P., Hendy, E. B., Pijacka, W., Marvar, P., Moraes, D. J., et al. (2013). The carotid body as a putative therapeutic target for the treatment of neurogenic hypertension. Nat. Commun. 4, 2395. doi: 10.1038/ncomms3395

McQueen, D. S. (1983). "Pharmacological aspects of putative transmitters in the carotid body," in Physiology of the Peripheral Arterial Chemoreceptors, eds H. Acker and R. G. O'Regan (Amesterdam: Elsevier Science), 149-155.

McQueen, D. S., and Ribeiro, J. A. (1981). Effect of adenosine on carotid chemoreceptor activity in the cat. Br. J. Pharmacol. 74, 129-136. doi: 10.1111/j.14765381.1981.tb09964.x

Meza, R. C., Ortiz, F. C., Bravo, E., Iturriaga-Vásquez, P., Eugenín, J. L., and Varas, R. (2012). Functional expression of the $\alpha 7$ and $\alpha 4$-containing nicotinic acetylcholine receptors on the neonatal rat carotid body. Neurochem. Int. 60, 115-124. doi: 10.1016/j.neuint.2011.11.011

Millen, J., MacLean, M. R., and Houslay, M. D. (2006). Hypoxia-induced remodelling of PDE4 isoform expression and cAMP handling in human pulmonary artery smooth muscle cells. Eur. J. Cell Biol. 85, 679-691. doi: 10.1016/j.ejcb.2006.01.006

Mir, A. K., McQueen, D. S., Pallot, D. J., and Nahorski, S. R. (1984). Direct biochemical and neuropharmacological identification of dopamine D2-receptors in the rabbit carotid body. Brain Res. 291, 273-283. doi: 10.1016/00068993(84)91259-9

Mir, A. K., Pallot, D. J., and Nahorski, S. R. (1983). Biogenic amine-stimulated cyclic adenosine- $3^{\prime}, 5^{\prime}$-monophosphate formation in the rat carotid body. J. Neurochem. 41, 663-669. doi: 10.1111/j.1471-4159.1983.tb04792.x

Mokashi, A., Roy, A., Rozanov, C., Daudu, P., DiGuilio, C., and Lahiri, S. (2001). Ryanodine receptor-mediated $[\mathrm{Ca}(2+)](\mathrm{i})$ release in glomus cells is independent of natural stimuli and does not participate in the chemosensory responses of the rat carotid body. Brain Res. 916, 32-40. doi: 10.1016/S0006-8993(01)02860-8

Monteiro, E. C., and Ribeiro, J. A. (1987). Ventilatory effects of adenosine mediated by carotid body chemoreceptors in the rat. Naunyn. Schmiedebergs. Arch. Pharmacol. 335, 143-148. doi: 10.1007/BF00177715

Monteiro, T. C., Batuca, J. R., Obeso, A., González, C., and Monteiro, E. C. (2011). Carotid body function in aged rats: responses to hypoxia, ischemia, dopamine, and adenosine. Age (Dordr). 33, 337-350. doi: 10.1007/s11357-010-9187-z

Niane, L., Joseph, V., and Bairam, A. (2009). Role of cholinergic-nicotinic receptors on hypoxic chemoreflex during postnatal development in rats. Respir. Physiol. Neurobiol. 169, 323-332. doi: 10.1016/j.resp.2009.09.014

Nunes, A. R., Batuca, J. R., and Monteiro, E. C. (2010). Acute hypoxia modifies cAMP levels induced by inhibitors of phosphodiesterase- 4 in rat carotid bodies, carotid arteries and superior cervical ganglia. Br. J. Pharmacol. 159, 353-361. doi: 10.1111/j.1476-5381.2009.00534.x

Nunes, A. R., Holmes, A. P. S., Sample, V., Kumar, P., Cann, M. J., Monteiro, E. C., et al. (2013). Bicarbonate-sensitive soluble and transmembrane adenylyl cyclases in peripheral chemoreceptors. Respir. Physiol. Neurobiol. 188, 83-93. doi: 10.1016/j.resp.2013.05.013

Nunes, A. R., Monteiro, E. C., Johnson, S. M., and Gauda, E. B. (2009). Bicarbonate-regulated soluble adenylyl cyclase (sAC) mRNA expression and activity in peripheral chemoreceptors. Adv. Exp. Med. Biol. 648, 235-241. doi: 10.1007/978-90-481-2259-2_27

Nurse, C. A. (2014). Synaptic and paracrine mechanisms at carotid body arterial chemoreceptors. J. Physiol. 592(Pt 16), 3419-3426. doi: 10.1113/jphysiol.2013.269829

O’Keefe, J. H., Bhatti, S. K., Patil, H. R., DiNicolantonio, J. J., Lucan, S. C., and Lavie, C. J. (2013). Effects of habitual coffee consumption on cardiometabolic disease, cardiovascular health, and all-cause mortality. J. Am. Coll. Cardiol. 62, 1043-1051. doi: 10.1016/j.jacc.2013.06.035

Obeso, A., Gómez-Niño, M. A., Almaraz, L., Dinger, B., Fidone, S., and González, C. (1997). Evidence for two types of nicotinic receptors in the cat carotid body chemoreceptor cells. Brain Res. 754, 298-302.

Oomori, Y., Nakaya, K., Tanaka, H., Iuchi, H., Ishikawa, K., Satoh, Y., et al. (1994). Immunohistochemical and histochemical evidence for the presence of noradrenaline, serotonin and gamma-aminobutyric acid in chief cells of the mouse carotid body. Cell Tissue Res. 278, 249-254. doi: 10.1007/BF00414167

Pastor-Soler, N., Beaulieu, V., Litvin, T. N., Da Silva, N., Chen, Y., Brown, D., et al. (2003). Bicarbonate-regulated adenylyl cyclase (sAC) is a sensor that regulates $\mathrm{pH}$-dependent V-ATPase recycling. J. Biol. Chem. 278, 49523-49529. doi: 10.1074/jbc.M309543200

Peng, Y.-J., Yuan, G., Ramakrishnan, D., Sharma, S. D., Bosch-Marce, M., Kumar, G. K., et al. (2006). Heterozygous HIF-1alpha deficiency impairs carotid bodymediated systemic responses and reactive oxygen species generation in mice exposed to intermittent hypoxia. J. Physiol. 577, 705-716. doi: 10.1113/jphysiol.2006.114033

Pérez-García, M. T., Almaraz, L., and González, C. (1990). Effects of different types of stimulation on cyclic AMP content in the rabbit carotid body: functional significance. J. Neurochem. 55, 1287-1293. doi: 10.1111/j.14714159.1990.tb03137.x

Pérez-García, M. T., Almaraz, L., and González, C. (1991). Cyclic AMP modulates differentially the release of dopamine induced by hypoxia and other stimuli and increases dopamine synthesis in the rabbit carotid body. J. Neurochem. 57, 1992-2000. doi: 10.1111/j.1471-4159.1991.tb06414.x

Pérez-García, M. T., Gómez-Niño, A., Almaraz, L., and González, C. (1993). Neurotransmitters and second messenger systems in the carotid body. Adv. Exp. Med. Biol. 337, 279-287.

Pierre, S., Eschenhagen, T., Geisslinger, G., and Scholich, K. (2009). Capturing adenylyl cyclases as potential drug targets. Nat. Rev. Drug Discov. 8, 321-335. doi: $10.1038 / \operatorname{nrd} 2827$

Porzionato, A., Fenu, G., Rucinski, M., Macchi, V., Montella, A., Malendowicz, L. K., et al. (2011). KISS1 and KISS1R expression in the human and rat carotid body and superior cervical ganglion. Eur. J. Histochem. 55, e14. doi: 10.4081/ejh.2011.e14

Porzionato, A., Macchi, V., Parenti, A., and De Caro, R. (2008). Trophic factors in the carotid body. Int. Rev. Cell Mol. Biol. 269, 1-58. doi: 10.1016/S19376448(08)01001-0

Prabhakar, N. R., Kou Yu, R., and Runold, M. (1990). Chemoreceptor responses to substance $\mathrm{P}$, physalaemin and eledoisin: evidence for neurokinin-1 receptors in the cat carotid body. Neurosci. Lett. 120, 183-186. doi: 10.1016/03043940(90)90033-6

Prabhakar, N. R., and Peng, Y.-J. (2004). Peripheral chemoreceptors in health and disease. J. Appl. Physiol. 96, 359-366. doi: 10.1152/japplphysiol.00809. 2003

Prasad, M., Fearon, I. M., Zhang, M., Laing, M., Vollmer, C., and Nurse, C. A. (2001). Expression of P2X2 and P2X3 receptor subunits in rat carotid body afferent neurones: role in chemosensory signalling. J. Physiol. 537, 667-677. doi: 10.1113/jphysiol.2001.012836

Prieto-Lloret, J., Donnelly, D. F., Rico, A. J., Moratalla, R., González, C., and Rigual, R. J. (2007). Hypoxia transduction by carotid body chemoreceptors in mice lacking dopamine $\mathrm{D}(2)$ receptors. J. Appl. Physiol. 103, 1269-1275. doi: 10.1152/japplphysiol.00391.2007 
Ramirez, M., Almaraz, L., Gonzalez, C., and Rocher, A. (2012). Cyclic AMP and Epac contribute to the genesis of the positive interaction between hypoxia and hypercapnia in the carotid body. Adv. Exp. Med. Biol. 758, 215-223. doi: 10.1007/978-94-007-4584-1_30

Reid, P. G., Watt, A. H., Penny, W. J., Newby, A. C., Smith, A. P., and Routledge, P. A. (1991). Plasma adenosine concentrations during adenosine-induced respiratory stimulation in man. Eur. J. Clin. Pharmacol. 40, 175-180.

Rennard, S. I., Sun, S. X., Tourkodimitris, S., Rowe, P., Goehring, U. M., Bredenbröker, D., et al. (2014). Roflumilast and dyspnea in patients with moderate to very severe chronic obstructive pulmonary disease: a pooled analysis of four clinical trials. Int. J. Chron. Obstruct. Pulmon. Dis. 9, 657-673. doi: 10.2147/COPD.S55738

Rey, S., Del Rio, R., and Iturriaga, R. (2006). Contribution of endothelin-1 to the enhanced carotid body chemosensory responses induced by chronic intermittent hypoxia. Brain Res. 1086, 152-159. doi: 10.1016/j.brainres.2006.02.082

Ribeiro, J. A., and Sebastião, A. M. (2010). Modulation and metamodulation of synapses by adenosine. Acta Physiol. (Oxf). 199, 161-169. doi: 10.1111/j.17481716.2010.02115.x

Ribeiro, M. J., Sacramento, J. F., Gonzalez, C., Guarino, M. P., Monteiro, E. C., and Conde, S. V. (2013). Carotid body denervation prevents the development of insulin resistance and hypertension induced by hypercaloric diets. Diabetes 62, 2905-2916. doi: 10.2337/db12-1463

Rindler, M. J., Bashor, M. M., Spitzer, N., and Saier, M. H. (1978). Regulation of adenosine $3^{\prime}: 5^{\prime}$-monophosphate efflux from animal cells. J. Biol. Chem. 253, 5431-5436.

Rocher, A., Caceres, A. I., Almaraz, L., and Gonzalez, C. (2009). EPAC signalling pathways are involved in low PO2 chemoreception in carotid body chemoreceptor cells. J. Physiol. 587, 4015-4027. doi: 10.1113/jphysiol.2009.172072

Rocher, A., Gonzalez, C., and Almaraz, L. (1999). Adenosine inhibits L-type Ca2+ current and catecholamine release in the rabbit carotid body chemoreceptor cells. Eur. J. Neurosci. 11, 673-681. doi: 10.1046/j.1460-9568.1999.00470.x

Rong, W., Gourine, A. V., Cockayne, D. A., Xiang, Z., Ford, A. P. D. W., Spyer, K. M., et al. (2003). Pivotal role of nucleotide P2X2 receptor subunit of the ATPgated ion channel mediating ventilatory responses to hypoxia. J. Neurosci. 23, 11315-11321

Roy, A., Derakhshan, F., and Wilson, R. J. A. (2013). Stress peptide PACAP engages multiple signaling pathways within the carotid body to initiate excitatory responses in respiratory and sympathetic chemosensory afferents. Am. J. Physiol. Regul. Integr. Comp. Physiol. 304, R1070-R1084. doi: 10.1152/ajpregu.00465.2012

Sample, V., Mehta, S., and Zhang, J. (2014). Genetically encoded molecular probes to visualize and perturb signaling dynamics in living biological systems. J. Cell Sci. 127, 1151-1160. doi: 10.1242/jcs.099994

Schmid, A., Sutto, Z., Nlend, M.-C., Horvath, G., Schmid, N., Buck, J., et al. (2007). Soluble adenylyl cyclase is localized to cilia and contributes to ciliary beat frequency regulation via production of cAMP. J. Gen. Physiol. 130, 99-109. doi: 10.1085/jgp.200709784

Schultz, H. D. (2011). Angiotensin and carotid body chemoreception in heart failure. Curr. Opin. Pharmacol. 11, 144-149. doi: 10.1016/j.coph.2010.12.004

Schultz, H. D., Marcus, N. J., and Del Rio, R. (2013). Role of the carotid body in the pathophysiology of heart failure. Curr. Hypertens. Rep. 15, 356-362. doi: 10.1007/s11906-013-0368-x

Sciaraffia, E., Riccomi, A., Lindstedt, R., Gesa, V., Cirelli, E., Patrizio, M., et al. (2014). Human monocytes respond to extracellular cAMP through A2A and A2B adenosine receptors. J. Leukoc. Biol. 96, 113-122. doi: 10.1189/jlb.3A0513302RR

Shirahata, M., Balbir, A., Otsubo, T., and Fitzgerald, R. S. (2007). Role of acetylcholine in neurotransmission of the carotid body. Respir. Physiol. Neurobiol. 157, 93-105. doi: 10.1016/j.resp.2006.12.010

Shirahata, M., Hirasawa, S., Okumura, M., Mendoza, J. A., Okumura, A., Balbir, A., et al. (2004). Identification of M1 and M2 muscarinic acetylcholine receptors in the cat carotid body chemosensory system. Neuroscience 128, 635-644. doi: 10.1016/j.neuroscience.2004.06.068

Shirahata, M., Ishizawa, Y., Rudisill, M., Schofield, B., and Fitzgerald, R. S. (1998). Presence of nicotinic acetylcholine receptors in cat carotid body afferent system. Brain Res. 814, 213-217. doi: 10.1016/S0006-8993(98)01015-4

Spoto, G., Di Giulio, C., Contento, A., and Di Stilio, M. (1998). Hypoxic and hyperoxic effect on blood phosphodiesterase activity in young and old rats. Life Sci. 63, PL349-PL353. doi: 10.1016/S0024-3205(98)00513-X
Stea, A., Jackson, A., Macintyre, L., and Nurse, C. A. (1995). Long-term modulation of inward currents in $\mathrm{O} 2$ chemoreceptors by chronic hypoxia and cyclic AMP in vitro. J. Neurosci. 15, 2192-2202.

Stea, A., Jackson, A., and Nurse, C. A. (1992). Hypoxia and N6,O2'dibutyryladenosine $3^{\prime}, 5^{\prime}$-cyclic monophosphate, but not nerve growth factor, induce $\mathrm{Na}+$ channels and hypertrophy in chromaffin-like arterial chemoreceptors. Proc. Natl. Acad. Sci. U.S.A. 89, 9469-9473. doi: 10.1073/pnas.89.20.9469

Stulbarg, M. S., Winn, W. R., and Kellett, L. E. (1989). Bilateral carotid body resection for the relief of dyspnea in severe chronic obstructive pulmonary disease. Physiologic and clinical observations in three patients. Chest 95, 1123-1128. doi: 10.1378/chest.95.5.1123

Summers, B. A., Overholt, J. L., and Prabhakar, N. R. (2002). CO(2) and pH independently modulate L-type $\mathrm{Ca}(2+)$ current in rabbit carotid body glomus cells. J. Neurophysiol. 88, 604-612.

Sun, X. C., Cui, M., and Bonanno, J. A. (2004). [HCO3-]-regulated expression and activity of soluble adenylyl cyclase in corneal endothelial and Calu-3 cells. BMC Physiol. 4:8. doi: 10.1186/1472-6793-4-8

Sztrymf, B., Chevrel, G., Bertrand, F., Margetis, D., Hurel, D., Ricard, J.-D., et al. (2010). Beneficial effects of loxapine on agitation and breathing patterns during weaning from mechanical ventilation. Crit. Care 14, R86. doi: 10.1186/cc9015

Taylor, S. S., Buechler, J. A., and Yonemoto, W. (1990). cAMP-dependent protein kinase: framework for a diverse family of regulatory enzymes. Annu. Rev. Biochem. 59, 971-1005. doi: 10.1146/annurev.bi.59.070190.004543

Thompson, C. M., Troche, K., Jordan, H. L., Barr, B. L., and Wyatt, C. N. (2010). Evidence for functional, inhibitory, histamine $\mathrm{H} 3$ receptors in rat carotid body Type I cells. Neurosci. Lett. 471, 15-19. doi: 10.1016/j.neulet.2009.12.077

Thompson, C. M., and Wyatt, C. N. (2011). Inhibition of adenylate cyclase attenuates muscarinic $\mathrm{Ca}^{2}(+)$ signaling by a PKA-independent mechanism in rat carotid body Type I cells. Respir. Physiol. Neurobiol. 175, 90-96. doi: 10.1016/j.resp.2010.09.013

Townsend, P. D., Holliday, P. M., Fenyk, S., Hess, K. C., Gray, M. A., Hodgson, D. R. W., et al. (2009). Stimulation of mammalian G-protein-responsive adenylyl cyclases by carbon dioxide. J. Biol. Chem. 284, 784-791. doi: 10.1074/jbc.M807239200

Van de Borne, P., Oren, R., and Somers, V. K. (1998). Dopamine depresses minute ventilation in patients with heart failure. Circulation 98, 126-131. doi: 10.1161/01.CIR.98.2.126

Vicario, I., Obeso, A., Rocher, A., López-Lopez, J. R., and González, C. (2000b). Intracellular $\mathrm{Ca}(2+)$ stores in chemoreceptor cells of the rabbit carotid body: significance for chemoreception. Am. J. Physiol. Cell Physiol. 279, C51-C61

Vicario, I., Rigual, R., Obeso, A., and Gonzalez, C. (2000a). Characterization of the synthesis and release of catecholamine in the rat carotid body in vitro. Am. J. Physiol. Cell Physiol. 278, C490-C499.

Wang, W. J., Cheng, G. F., Dinger, B. G., and Fidone, S. J. (1989). Effects of hypoxia on cyclic nucleotide formation in rabbit carotid body in vitro. Neurosci. Lett. 105, 164-168. doi: 10.1016/0304-3940(89)90030-X

Wang, W. J., Cheng, G. F., Yoshizaki, K., Dinger, B., and Fidone, S. (1991a). The role of cyclic AMP in chemoreception in the rabbit carotid body. Brain Res. 540, 96-104. doi: 10.1016/0006-8993(91)90495-H

Wang, X., Wang, B.-R., Duan, X.-L., Zhang, P., Ding, Y.-Q., Jia, Y., et al. (2002a). Strong expression of interleukin-1 receptor type $I$ in the rat carotid body. J. Histochem. Cytochem. 50, 1677-1684. doi: 10.1177/0022155402050 01213

Wang, Z.-Y., Keith, I. M., Beckman, M. J., Brownfield, M. S., Vidruk, E. H., and Bisgard, G. E. (2000). 5-HT5a receptors in the carotid body chemoreception pathway of rat. Neurosci. Lett. 278, 9-12. doi: 10.1016/S0304-3940(99) 00905-2

Wang, Z.-Y., Keith, I. M., Olson, E. B., Vidruk, E. H., and Bisgard, G. E. (2002b). Expression of 5-HT3 receptors in primary sensory neurons of the petrosal ganglion of adult rats. Auton. Neurosci. 95, 121-124. doi: 10.1016/S15660702(01)00384-8

Wang, Z. Z., Stensaas, L. J., de Vente, J., Dinger, B., and Fidone, S. J. (1991b). Immunocytochemical localization of cAMP and cGMP in cells of the rat carotid body following natural and pharmacological stimulation. Histochemistry 96, 523-530. doi: 10.1007/BF00267078

Watt, A. H., Reid, P. G., Stephens, M. R., and Routledge, P. A. (1987). Adenosineinduced respiratory stimulation in man depends on site of infusion. Evidence for an action on the carotid body? Br. J. Clin. Pharmacol. 23, 486-490. doi: 10.1111/j.1365-2125.1987.tb03081.x 
Welsh, M. J., Heistad, D. D., and Abboud, F. M. (1978). Depression of ventilation by dopamine in man. Evidence for an effect on the chemoreceptor reflex. J. Clin. Invest. 61, 708-713. doi: 10.1172/JCI108983

Whipp, B. J., and Ward, S. A. (1992). Physiologic changes following bilateral carotid-body resection in patients with chronic obstructive pulmonary disease. Chest 101, 656-661. doi: 10.1378/chest.101.3.656

$\mathrm{Xu}, \mathrm{F}$, Tse, F. W., and Tse, A. (2007). Pituitary adenylate cyclase-activating polypeptide (PACAP) stimulates the oxygen sensing type I (glomus) cells of rat carotid bodies via reduction of a background TASK-like K+ current. J. Neurochem. 101, 1284-1293. doi: 10.1111/j.1471-4159.2007.04468.x

$\mathrm{Xu}, \mathrm{F} ., \mathrm{Xu}, \mathrm{J} .$, Tse, F. W., and Tse, A. (2006). Adenosine stimulates depolarization and rise in cytoplasmic [Ca2+] in type I cells of rat carotid bodies. Am. J. Physiol. Cell Physiol. 290, C1592-C1598. doi: 10.1152/ajpcell.00546.2005

$\mathrm{Xu}$, J., Tse, F. W., and Tse, A. (2003). ATP triggers intracellular Ca2+ release in type II cells of the rat carotid body. J. Physiol. 549, 739-747. doi: 10.1113/jphysiol.2003.039735

$\mathrm{Xu}$, J., Xu, F., Tse, F. W., and Tse, A. (2005). ATP inhibits the hypoxia response in type I cells of rat carotid bodies. J. Neurochem. 92, 1419-1430. doi: 10.1111/j.1471-4159.2004.02978.x

Zapata, P. (1975). Effects of dopamine on carotid chemo- and baroreceptors in vitro. J. Physiol. 244, 235-251.

Zhang, M., Clarke, K., Zhong, H., Vollmer, C., and Nurse, C. A. (2009) Postsynaptic action of GABA in modulating sensory transmission in co-cultures of rat carotid body via GABA(A) receptors. J. Physiol. 587, 329-344. doi: 10.1113/jphysiol.2008.165035
Zhang, M., Fearon, I. M., Zhong, H., and Nurse, C. A. (2003). Presynaptic modulation of rat arterial chemoreceptor function by 5 -HT: role of $\mathrm{K}+$ channel inhibition via protein kinase C. J. Physiol. 551, 825-842. doi: 10.1113/jphysiol.2002.038489

Zhong, H., and Nurse, C. A. (1997). Nicotinic acetylcholine sensitivity of rat petrosal sensory neurons in dissociated cell culture. Brain Res. 766, 153-161. doi: 10.1016/S0006-8993(97)00526-X

Conflict of Interest Statement: The authors declare that the research was conducted in the absence of any commercial or financial relationships that could be construed as a potential conflict of interest.

Received: 27 August 2014; accepted: 01 October 2014; published online: 28 October 2014.

Citation: Nunes AR, Holmes AP, Conde SV, Gauda EB and Monteiro EC (2014) Revisiting CAMP signaling in the carotid body. Front. Physiol. 5:406. doi: 10.3389/ fphys.2014.00406

This article was submitted to Integrative Physiology, a section of the journal Frontiers in Physiology.

Copyright (c) 2014 Nunes, Holmes, Conde, Gauda and Monteiro. This is an openaccess article distributed under the terms of the Creative Commons Attribution License (CC BY). The use, distribution or reproduction in other forums is permitted, provided the original author(s) or licensor are credited and that the original publication in this journal is cited, in accordance with accepted academic practice. No use, distribution or reproduction is permitted which does not comply with these terms. 